\title{
Studies on the Chromosome Numbers in Higher Plants, with Special Reference to Cytokinesis, I.
}

\author{
By
}

T. Sugiura

Osaka High School, Osaka

Receivud June 25, 1933 *

Contents

1. Introduction. .

2. Materials and Methods.

3. Chromosome Numbers, Descriptions and Discussions.

4. Cleavage Furrow.

5. Summary.

6. References.

\section{Introduction}

The pioneer study of chromosome numbers in higher plants was that in Lilium by Strasburger in 1882, but in spite of a lapse of more than 50 years the determinations of chromosome numbers in higher plants was far from being complete, as are seen from the well known lists by Tischler (1921-34) and Gaiser (1926-1934).

Even now there is no account of chromosome numbers in some families. On the other hand, the examples of the partition wall formations in pollen mother cells by protoplasmic furrowing which was first noticed by Guignard (1897) and was energetically studied by Farr (1916) afterwards, were still very few in dicotyledons although Yamaha (1926) found 19 cases in addition to those formerly known. Yasui's observations (1931) are also to be noted here.

The writer having endeavoured for years to determine chromosome numbers in higher plants as many as possible and also to study protoplasmic furrowing considers that it is not meaningless to describe some of the results hitherto obtained.

\section{Materials and Methods}

On account of studying various chromosomes of many dicotyledonous plants belonging to various families and genera in a wide scope, against the study of polyploidal chromosomes in certain genera which are now going on hither and thither, I have collected a great many seeds as possible covering the majority of families mostly in Dicotyledoneae, some

* The publication of this paper has been delayed, because of certain technical circumstances and of its length which surpasses the limit fixed by the regulations of the Journal. 
of which were sent from abroad. I desire to express my best thanks to Dr. Nakai, the director of the Koishikawa Botanical Garden and to the Director of the Musée d'Histoire Naturelle de Paris and the director of the Botanic Garden of Madrid for the supply of valuable seeds.

According to my experience during the past 10 years, our modified Farmer's fluid ( 6 parts abs. alcohol +1 part glacial acetic acid) is not only recommended for the fixation of flower-buds, but also for root-tips as well for the study of chromosome numbers. In the present work this fluid was exclusively employed, and for staining Heidenhain's iron-alum haematoxilin was used.

In order to ascertain how long our alcohol acetic mixture could retain its original fixing power, I used Hellige's comparator to measure its $\mathrm{pH}$ value. As a result of this experiment it is clearly shown in the following tables that the present fixing fluid retains its qualities so far as its $\mathrm{pH}$ is concerned at least for three months if kept in a hardglass bottle well sealed by vaseline and without any superfluous air space.

Recently quicker methods of fixing and staining such as Heitz's, Sinotô's, Belling's, Geitler's, etc. have been generally used for plant karyo-

Fixing fluid in a bottle well sealed by vaseline

\begin{tabular}{|c|c|}
\hline Date & $\mathrm{pH}$ \\
\hline Dec. 6 & 1.8 \\
\hline $\begin{array}{l}\text {, } \quad 17 \\
97\end{array}$ & 1.9 \\
\hline Jä. 18 & $\begin{array}{l}1.9 \\
1.9\end{array}$ \\
\hline Feb. 13 & 1.9 \\
\hline Mar. 6 & 1.9 \\
\hline May 29 & 2.1 \\
\hline June 12 & 2.3 \\
\hline
\end{tabular}

Fixing fluid in a bottle not well sealed by vaseline

\begin{tabular}{cr|c}
\hline \multicolumn{2}{|c|}{ Date } & pH \\
\hline Sep. & 12 & 1.8 \\
" & 15 & 1.9 \\
Oct. 26 & 2.0 \\
Nov. 22 & 2.1 \\
Dec. & 2.3 \\
& & 2.4
\end{tabular}

logy, especially for the purpose of chromosome count. But I have continued the method I have adopted since 1920 in the study of chromosome numbers (Sugiura 1928, 1931, 1936), because the use of different fixing and staining methods makes it difficult to compare the size and shape of chromosomes.

Almost all materials were cut as thick as 14 micra in order to secure complete nuclei in a section. Still in the cases of Crinum, Michelia and Adonis, cutting the nuclei into a few sections occurred several times, even when they were cut more than 20 micra in thickness.

The passages of alcohol for dehydration of the fixed materials were made through $50 \%, 60 \%, 80 \%, 95 \%$ and $100 \%$. Similar abbreviations in dehydration were also made by Sakamura (1920), Rin (unpublished), Yamaha (1925), Sinotô (1929), \&c. and were found sufficient for the purpose of chromosome counts.

All the figures were drawn, with some exceptions, by the use of a Leitz 1/12a objective and a Zeiss comp. ocular 20, magnifying about 3330 times, and were reduced in reproduction to $9 / 10$. The exceptional magnifications are given under each figure. 


\section{Chromosome Numbers}

\section{Compositae}

Descriptions and Discussions ${ }^{1)}$

Since Tahara's well known studies (1915, etc.) about the Chrysanthemum, karyological studies in this family have been extensively made by many other workers.

In the present work, 5 species in 5 genera were submitted to the chromosome counts (cf. Table 1 ).

Ammobium alatum (Fig. 1). The meiotic chromosome number (12) is rarer among various meiotic chromosome numbers hitherto known in Compositae; i.e. it is only found in Hemizonis, Centaures, Lactuca, Cosmos and the present species. Tetrads are cross shaped.

Arctium Lappa (Fig. 2). 32 Somatic chromosomes are irregular in length.

\section{Campanulaceae}

In this family the genera formerly studied karyologically are as follows : Cam panula (Overton, 1905, Armand 1912, E. Marchal 1920, Gairdner 1926, de Vilmorin et Simonet 1927; de Souza Violante 1929, Gairdner and Darlington, 1930); Adenophora, Specularia (Marchal 1920); Phyteuma (Marchal, Armand 1912); Codonopsis, Hedraeanthus, Platycodon (Marchal 1920); Symphyandra (de Vilmorin et Simonet 1927); Lobelia (Armand 1912, de Vilmorin et Simonet 1927).

Lobelia. Various chromosome numbers are found in Campanla (in about 35 species), but these numbers have few multiple relations like those of Carex, i.e. 8, 10,13,16,17,34, 51. The same relation among the chromosome numbers is also applicable to Lobelia. In this genus the meiotic chromosome numbers found up to this date were $7,8,9,14,21$ (Armand 1912, de Vilmorin et Simonet 1927). The meiotic numbers 7 , 9,21 were also found by the present author.

Lobelia cardinalis (Fig. 7). The $\mathrm{PMC}^{2)}$ are relatively smaller than those of $L$. ramosa. On the contrary, the meiotic chromosomes (7) are much larger than those of the latter. Mitotic figures from metaphase to interphase are to be seen in the anther. (de Vilmorin et Simonet $1927, \mathrm{n}=7$.)

L. ramosa (Fig. 8). The PMC are much larger than those of L. cardinalis and L. speciosa. The meiotic number of chromosomes is 9 . (de Vilmorin et Simonet 1927, $\mathrm{n}=9$.)

\section{Valerianaceae}

The chromosome numbers in this family have been already known in several genera, namely Valeriana (Asplund 1920, Meurman 1924-5, Senjaninova 1927), Centranthus (Asplund 1920) and Partrinia (Asplund 1920).

1) The following descriptions and discussions are made as concise as possible; therefore for the species not described below, refer to the table.

2) $\mathrm{PMC}=$ pollen mother cell or cells. 
Patrinia scabiosaefolia (Fig. 10) has 11 meiotic chromosomes. (Asplud 1920, $\mathrm{n}=11$ in P. rupestris.)

\section{Caprifoliaceae}

It is strange that there are so few records of chromosome numbers in this family until recent time (Sax and Kribs 1930). The meiotic numbers formerly counted till 1929 were 9 in Lonicera stabiana (de Vilmorin et Simonet, 1927), 18 in L. alseuosmoides (De Vilmorin et Simonet, 1927), 18 in Sambuscus racemosa and nigra (Lagerberg 1909), and 18 in $S$. nigra (v. Boenicke, 1911 ; Winge, 1917 ; and Kleinmann, 1923).

Lonicera Marrowii, $\mathrm{n}=9$ (Fig. 11); Viburnum Awabuki, $\mathrm{n}=20$ (Fig. 12).

\section{Acanthaceae}

Karyological studies in this family have been very few. As to the meiotic chromosome number it was quite unknown until Gigante counted them in Acanthus mollis in 1929 , though even that count was uncertain.

Acanthus lusitanicus, $\mathrm{n}=28$ (Fig. 14). (Gigante 1929, $\mathrm{n}=24$ or $>24$ in A. mollis). The PMC is very large; $22 \mu \times 29 \mu$ at $\mathrm{IM}^{11}$ and $27 \mu \times 25 \mu$ at IIM. ${ }^{1}$

Ruellia ciliata (Fig. 16). Meiotic chromosomes, 18, are spherical; PMC $18 \mu$ in diameter at IIM.

R. tuberosa (Fig. 17). Meiotic chromosomes, 16, are short rodshaped; PMC $23 \mu \times 18 \mu$ at IM.

Thunbergia alata (Fig. 18). The PMC are conspicously larger ( $36 \mu \times 22 \mu$ at IM and $47 \mu \times 32 \mu$ at IIA. ${ }^{1)}$ ) in comparison with the chromosomes. The meiotic chromosome number is 9 . Tetrads are arranged on a plane instead of tetrahedronally so that they look like dyads in a side view. Similar examples are also observable in Lavatera trimestris, etc. In tapetum cells many amitotic nuclei are observed, while in those of Magnolia mitosis only takes place.

\section{Martyniaceae}

Martynia fragrans (Fig. 21). $\mathrm{n}=15 . \mathrm{PMC}$ is extraordinarilly large, $90 \mu \times 45 \mu$ at IIM.

\section{Pedaliaceae} (1929).

Of this family also there is no records of chromosome numbers except Morinaga's

Sesamum indicum (Fig. 20). White and black seed varieties were examined and found to have $2 \mathrm{n}=26$ chromosomes. (Morinaga et alii $1929, \mathrm{n}=13$ ).

\section{Gesneriaceae}

Formery only in 4 species 3 genera have been examined; viz. Ramondia Nathaliae, R. servica (Glisic 1924), Monophyllaea Horfieldii (Oehlker 1922), Kohleria refulgens

1) $I M=$ first metaphase ; IIM = second metaphase; IIA = second anapbase, etc. 
(Heitz 1926). We now add another 5 species in 5 genera; namely Corytholoma cardinalis, Naegelia zebrida, Sinningia speciosa, Saintpaulia ionantha and Streptocarpus Wendlandii.

These plants, being cultivated in our green house, have relatively larger anthers and show various stages of karyokinetic figures in one and the same anther; namely it contains various figures from first metaphasic to in terkinetic or even to homoeotypic stages. It was generally observed that the antifilamental end has older stages of meiotic figures than the filamental end.

Saintpaulia ionantha (Fig. 24). The size of floral buds is smaller in summer than in winter in the same meiotic stage. At diaphase 14 gemini are seen, but they are attached to each other more or less firmly, so that some of them look as if they were univalent.

Sinningia speciosa. The species cultivated in a green house is mistakenly called "Gloxinia." Materials used were Sutton's Monarch (Figs. 25, 26), Firefly (Fig. 27) and King-George V The size of the heterotypic chromosomes is very small in comparison with the size of cells. The size of homeotypic ones is, as small as $0.3 \mu$ in diameter. This size is the smallest of the 4 other genera studied in this family, in spite of the fact that the outer appearance of Sinningia is the largest of all. Polyspory is observed; the germination rate of grains is high. In young tapetum cells of this plant Golgi apparatus (?) was found.

Not only are these bodies found in tapetum cells but also in the somatic cells (root-tip-cells) of Forsythic suspensa just as Bensley found in Allium and as Guilliermond and Mangenot found in barley. But as to whether the bodies found in S. speciosa are similar to them or not is uncertain at present.

Streptocarpus Wendlandii (Fig. 28). $\mathrm{n}=16$. One sometimes classes Streptocarpus and Naegelia with Gesneriaceae and Saintpaulia and Sinningia with Cyrtandraceae on the bases of the ovarian situation. This attempt seems correct also from the karyological point of view, for the former two species have 16 and 12 gametic chromosomes (a multiple of 4), whereas the latter two have 14 and 28 (a multiple of 7) meiotic chromosomes respectively.

\section{Orobanchaceae}

Until recent time karyological studies in this family were quite few. Carter (1928) counted the number of chromosomes in Orobanche minor to be 19 in megasporogenesis.

Orobanche coerulescens var. typicus (Fig. 29) is widely distributed along sandy sea-shores where it usually grows as a parasite on Artemisia capillaris. The meiotic number of chromosomes is 20 .

\section{Bignoniaceae}

The cytological studies in this family were so few that only two genera and two species have thus far been studied; the number of chromosomes is as follows: Bignonia venusta, $\mathrm{n}=$ ca. 25 (Duggar 1899); Tecoma Tagliabuana, $\mathrm{n}=20$ (de Vilmorin et Simonet 1927). 

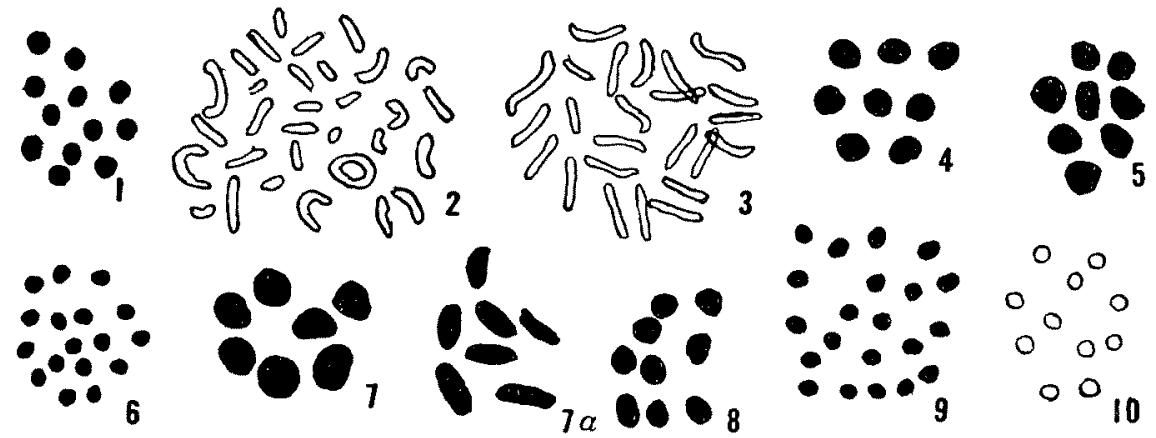

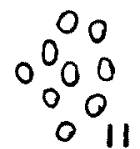<smiles>O=[Po](O)O[Na]</smiles>

000
8000
000013
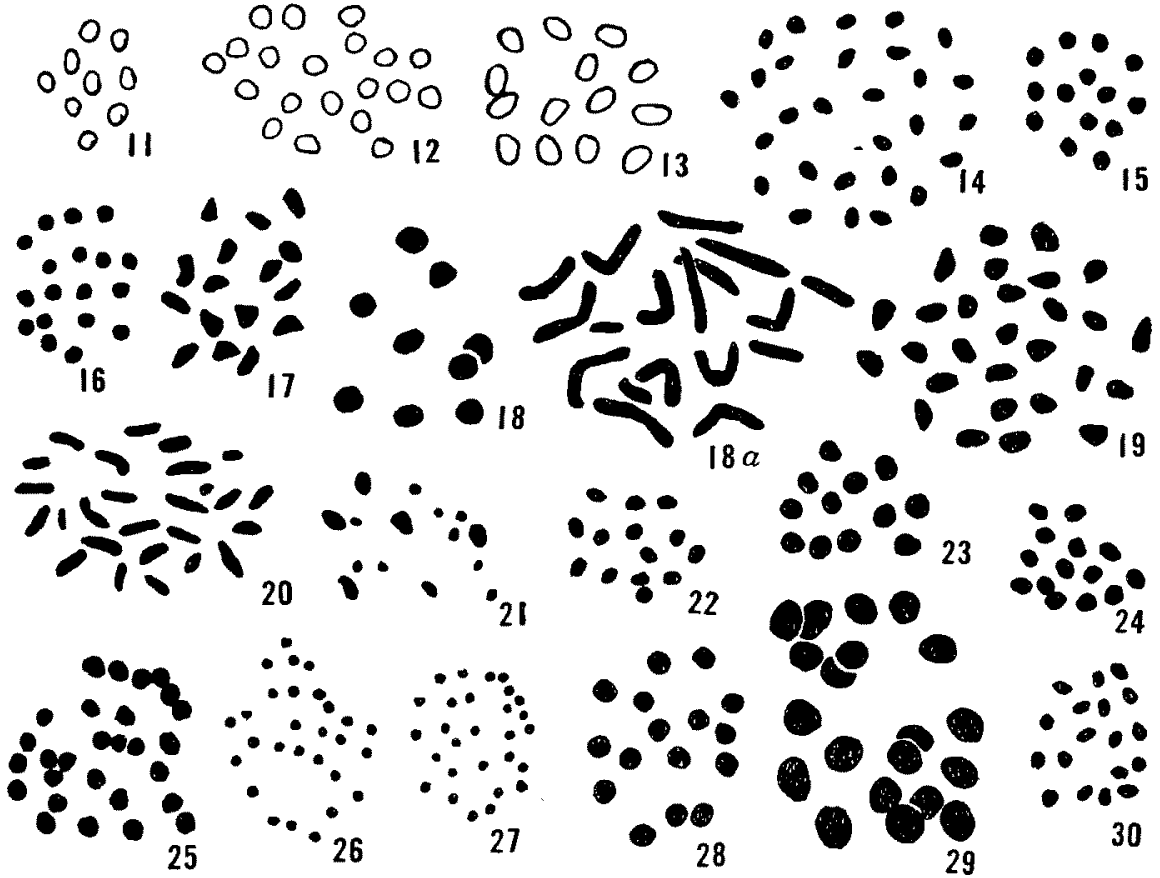

Figs. 1-30. 1. Ammobium alatum. IM. 2. Aretium Lappa (Takinogawa). Somatic nucler plate. 3. Cosmos bipinnatus. The same. 4. Felicia amelloides. IM. 5. Ursinia anethoides. IA. 6. Campanula punctata v. typica. IIM. 7. Lobelia cardinalis. IM. 7a. ditto. IA. 8. L. ramosa. IA. 9. L. speciosa. IM. 10. Patrinia secbiosasfolia. IIM. 11. Lonicera Marrowii. IA. 12. Viburnum Awabuki. IIM. 13. Phryma leptostachya. IM. 14. Acanthus lusitanicus. IM. 15. Justicia furcate. IM. 16. Ruellia ciliata. IIM. 17. $R$. tuberosa. IIM. 18. Thunbergia alata. IA. 18a. ditto. Somatic nuclear plate. 19. T. laurifolia. IM. 20. Sesamum indicum (Black seed). Somatic nuclear plate. 21. Martynia fragrans. IIM. 22. Corytholoma cardinalis. IIM. 23. Naegelia zebrina. IM. 24. Saintpaulia ionantha. IA. 25. Sinningia speciosa. IA (Monarch). 26. ditto. IIM. 27. ditto. IIM (Firefly) 28. Streptocarpus Wendlandii. IM. 29. Orobanche ammophila. IM. 30. Campsis grandiflora. IM. 
Tecoma Smithii (Figs. 33, 33a). $\mathrm{n}=18,2 \mathrm{n}=36$. Somatic chromosomes are very fine short rods. The PMC is large in comparison with the chromosomes it contains.

\section{Scrophulariaceae}

The karyological records in this farmily are becoming more and more numerous. Genera studied up to the present were Verbascum (Schmid 1906, Perino 1915, Håkansson 1926), Calceolaria (Heitz 1926, the present, writer 1928), Antirrhinum (Tischler 1920-22, Belling 1922, Baur 1924, Winge 1925, Heitz 1926-7), Pentastemon (Winge 1925, Heitz 1927), Veronica (Heitz 1926, Huber 1927), Digitalis (Haase-Bessell 1916, 1921, Warren 1924), Linaria (Heitz 1926-7, Tjebbes 1928), Cymbalaria (Heitz 1927), Chaenorrhinum Elatinoides (Heitz 1927), Asarina, Anarrhinum, Naurandia, Nemesia (Heitz 1927), Scrophularia (Håkansson 1926), Limosella (Svensson 1928), Torenia (Simon and Lowig 1930), Digitalis (Buxton, Newton, Huskins, Haase-Bessell 1923), Alectorolophus (Wilke 1930), Lathraea (Gates, Latter 1927).

Torenia Fournieri, $\mathrm{n}=9$ (Fig. 41) and T. Bailloni, $\mathrm{n}=8$ (Fig. 42) have a rather similar external appearance except for the flower color, though they have different chromosome numbers. Homeotypic chromosomes in both plants are almost equal in size, and their forms are not spherical but rather ellipsoidal. The extranucleoli are often found in T. Fournieri during heterotypic as well as homeotypic divisions, but it is scarcely found in T. Bailloni. Polyspory was not met with in $T$. Fournieri as described by Simon and Lowig (1930).

Penstemon barbatus (Fig. 39). Plants belonging to Penstemon (Pentastemon) have been investigated by Winge and Heitz. The former studied chiefly the meiotic number of chromosomes; the latter the somatic.

The species of Penstemon previously studied are such as $P$. confestus, deustus, diffusus, heterophyllus, isophyllus, unilateralis, venustus, Watsonii, Hartwegii hybridus, grandiflorus, Hartwegii var. hort. gloxinoides. Among them diffusus, grandiflorus, groxinoides, isophyllus were studied as to their meiotic chromosome number. The reduced number of chromosomes of the plants hitherto studied in Penstemon seems to be 8 .

Nycterinia capensis (Fig. 37). Meiotic chromosomes were counted to be 6, a number never found in this family except in Linaria (Heitz $1926,1927)$. In the old tapetum cells we often observed thick threadlike Golgi bodies.

$N$. selaginoides (Fig. 38). The external distinctions between this species and the former are as follows:

\begin{tabular}{l|c|c|c}
\hline \multicolumn{1}{c|}{ Plant names } & Leaves & Outside of corolla-tube & Height \\
\hline N. capensis & Linear or lanceolate & Short pubescent & $11 / 2 \mathrm{ft}$. \\
\hline N. selaginoides & Ovate or spatulate & Glabrous & $1 \mathrm{ft}$.
\end{tabular}


In spite of the facts that in these two species the external differences are rather small and their meiotic chromosome numbers are the same, the chromosomes of slaginoides are about two times longer than those of capensis.

\section{Solanaceae}

Formerly many species and varieties among Solanum, Nicotiana, Datura and Petunia were karyologically investigated by de Vilmorin et Simonet, J $\phi$ rgensen, R. E. Clausen, Goodspeed, Blackeslee, and others but the karyological studies of other genera of this family are still too scarce to mention here.

Capsicum annuum (Fig. 45). Up to the present two kinds of chromosome numbers were known in $C$. annuum varieties, the meiotic number of chromosomes being 6 (Kostoff 1926) and 12 (Margadant 1926, de Vilmorin et Simonet 1927, Huskins and La Cour 1930). We counted, however, 24 somatic chromosomes in this species. The somatic chromosomes of this plant are larger than those of the two other species described below, and some of them are bent. Recently Huskins and La Cour (1930) concluded that the meiotic number of chromosomes of annuum was 12 and not 6 as stated by Kostoff for several varieties.

Lycium chinense (Fig. 46). $\mathrm{n}=12$. (Morinaga et alii, 1929, $\mathrm{n}=12$.

Solanum Capsicastrum (Fig. 48) is a cultivated plant of Brazilian origin. 24 somatic chromosomes are found in this species which are much smaller and thicker than those of Capsicum and Lycium $(\mathrm{n}=12$, Jorgensen 1928, de Vilmorin et Simonet 1928, Huskin et La Cour 1930).

Browallia speciosa (Fig. 44) has conspicuously larger meiotic chromosomes than those of $B$. elata (11) (Fig. 43), though the stature of the former is just twice the latter.

Schizanthus wisetonensis (Fig. 47). The writer counted the meiotic number 10 in this species. This number is rather rare in this family. (Marchal 1920, $\mathrm{n}=10$ in $S$. pinnatus.)

\section{Nolanaceae}

Three genera and about 50 species belonging to this family are grown in Chiel, Peru and Bolivia. Cytological studies in this family were made by Campin (1925) and Whyte (1929b) on $N$. atriplicifolia and $N$. prostrata, the chromosome numbers of which are both 12 .

We studied 3 species whose meiotic chromosome numbers are all 12. (Cf. Table 1.)

\section{Labiatae}

Salvia. This genus includes far more than 500 species, many of which are used for ornamental, and some for culinary or medicinal purposes. The karyological records in this genus were very few. The writer studied karyologically S. argentea, coccinea, farinacea, pratensis 
var. tenorii and patens. Recently Rosmarinus, Scutellaria, Lavandula, Sideritis, Lamium, Galeopsis, Mentha and Salvia have also been studied by several cytologists. Among them many species in Salvia were studied by Scheel. According to him there seems to be different numbers of meiotic chromosomes in the varieties of S. pratensis; viz. 9 and 16. The writer's count in S. pratensis var. tenorii was, however, 10 (Fig. 56).

\section{Borraginaceae}

Formerly numbers of chromosomes were found in Heliotropium (Sevensson, 1925), Lycopsis (1925), and Myosotis (Winge, 1917). Quite recently Strey (1930) has published a lot of numbers of chromosomes of Boraginous plants containing 16 genera and 37 species. The writer has studied the following two genera and three species.

Anchusa italica (Fig. 63). Somatic number of chromosomes is 32 . (Strey 1930, 2n $=32$ ).

Echium plantagineum (Fig. 61), E. creticum (Fig. 62). The meiotic number of chromosomes in these two species is 8. (Strey 1930, $n=8$ in E. plantagineum.)

\section{Hydrophyllaceae}

Few studies of the chromosome numbers are known in this family except Winkler's Hydrophyllum (1921), Sevensson's Nemophila, Hydrolea (1925), Chittenden's Nemophila, Phacelia (1928), and my Nemophila, Phacelia (1928).

Phacelia campanularia (Fig 64). The meiotic chromosome number is 11. (Chittenden 1928, $\mathrm{n}=11$.)

$P$. tanacetifolia (Fig. 65) has 11 meiotic chromosomes. (Tjebbes $1928, \mathrm{n}=9$ ).

Nemophila Menziesii (Fig. 66). Heterotypic chromosomes are just the same in shape and number as those of N. Menziesii var. discoidalis, which were reported by the writer in 1928 . But the first meiotic chromosomes of this plant at metaphase are larger than those of discoidalis. In this plant it was observed that the furrowing prosess takes place already before the homoeotypic nuclear division is over. (Chittenden $1928, \mathrm{n}=9$.)

Wigandia Vigieri (Fig. 67). Three years elapsed from the time of germination of seeds to the bearing of flowers in our green house. Owing to the scarcity of floral materials its number of chromosomes has not been definitely determined, but several counts show that it is 22 as shown in Fig. 67. Since the antherial chambers in this plant contain a relatively larger amount of $\mathrm{PMC}$, various stages of karyokinetic figures can be observed in one antherial chamber, viz. first meiotic metaphase to interphase. The PMC and meiotic chromosomes in them are small in comparison with their gigantic external appearance. 
The interesting figures are often observed in the homeotypic division. After interphase both daughter nuclei twist each other so that they lie at a right angle or some other angles to each other; in some cases one daughter nucleus begins the next division while the other is still lying in the state of interkinesis.

Nuclei in filment cells of stamens contain needle like (if anything, more or less spindle like) protain crystals as in Campanula trachelium, etc. In addition to the usual tetrahedral figures, monoplanal figures are also observed as in the case of Collomia.

\section{Polemoniaceae}

Chromosome numbers in this family have hitherto been counted in the following plants : Cobaea scandens (Lawson 1898), Polemonium coerum (Winge 1923), P. reptans (Clausen 1929), Phlox Drummondii (Kelly 1920, '29), Gilia millefoliata (Schnarf 1921). We will now briefly describe four species of Gilia and two of Collomia.

Gilia tricolor (Fig. 69) has 9 meiotic chromosomes, two of which are smaller (almost spherical), the remaining ones being longer at the first metaphase. (Schnarf 1921, $\mathrm{n}=16$ in G. millefoliata.)

G. nivalis, G. multicaulis. $\mathrm{n}=9$. The elongated shape of the first meiotic chromosomes in these species are rather unique.

G. capitata (Fig. 68) has also shorter and longer meiotic chromosomes which are somewhat smaller than in the former species. These heteromorphous metaphasic chromosames become shorter in anaphase so that they are almost of the same size. These figures still maintain their size in interkinesis. The meiotic number of chromosomes in this plant is 8 , one of them being the shortest, 3 medium, 3 longer and one the longest at first metaphase.

Collomia coccinea (Fig. 72). Although the height of this herb is similar to that of the Gilia species, the PMC are, on the contrary, about twice as large as those of the latter. At the second anaphase the chromosomes (16) become long rods $(2 \times 0.5 \mu)$ like somatic chromosomes of Vicia Faba.

C. linearis has 8 haploid number of chromosomes (Fig. 73).

\section{Convolvulaceae}

Up to the present Calystegia (Kano 1920), Calonystion (Kano 1929), Convolvulus (Heitz 1926, Kano 1929), Ipomoea (Heitz 1926, Kano 1929), Pharbitis (Ohga 1916, Nagao 1928, Yasui 1928, Kano 1929) are the only genera in which chromosome numbers are known.

Ipomoea biloba (Fig. 74), a tropical sea-shore plant, was proved to have 15 meiotic chromosomes which is quite different to the former 


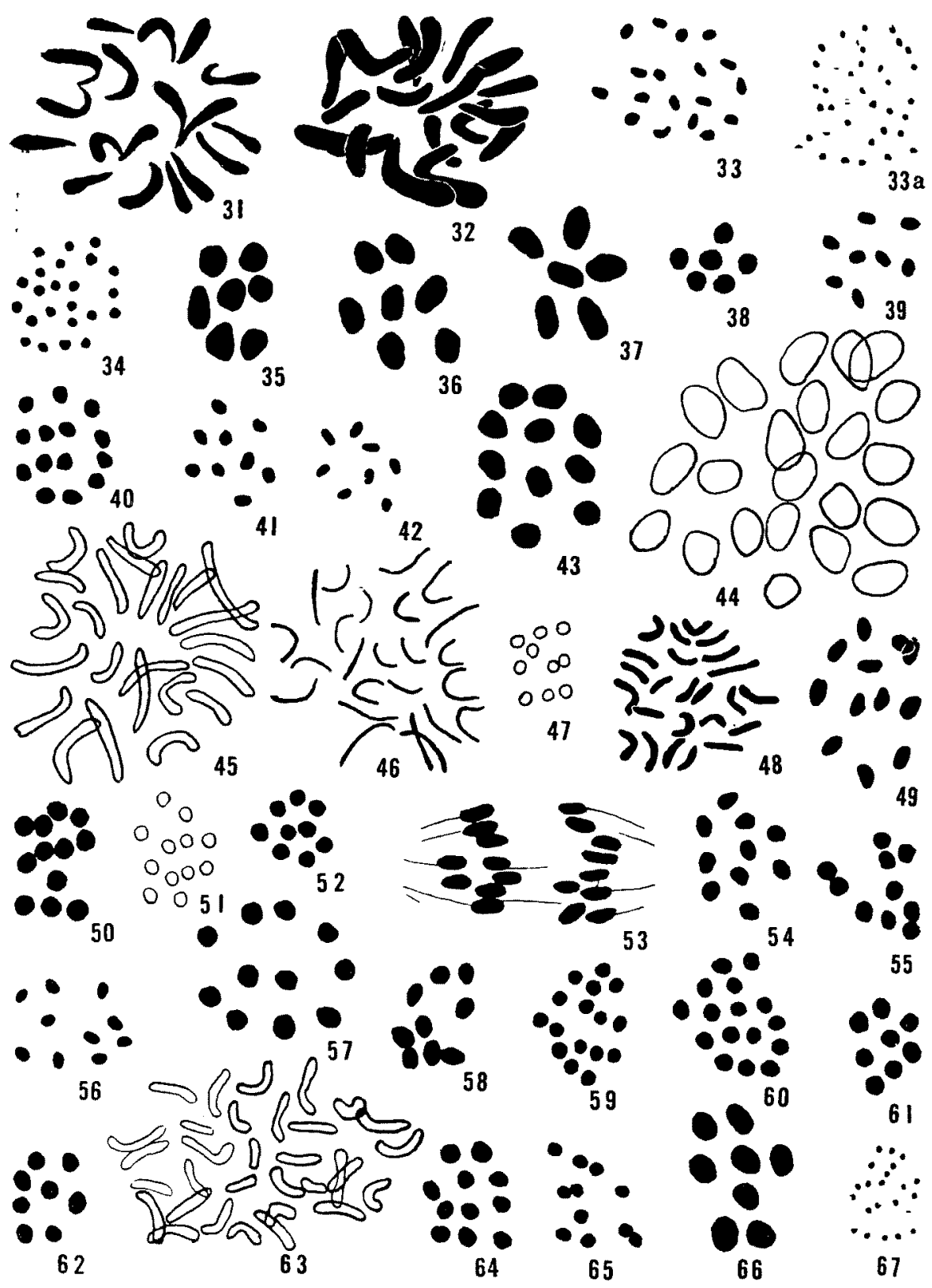

Figs. 31-67. 31. Incarvillea Delavayi. Somatic nuclear plate. 32. I. grandiflora. The same. 33. Tecoma Smithii. IM. 33 a. ditto. Somatic nuclear plate. 34 . Alonsoa Warscewiczii. IIM. 35. Collinsia candidissima. IA (polar view). 36. Hebenstreitia comosa. IM. 37. Nycterinia capensis. IM. 38. N. selaginoides. IA. 39. Penstemon barbatus. IM. 40. Rehmannia angulata. IIM. 41. Torenia Fourinieri. IIM. 42. T. Bailloni. IIM. 43. Browallia elata. IM. 44. B. speciosa. IM. 45. Capsicum annuum. Somatic nuclear plate. 46. Lycium chinense. 47. Schizanthus 
counts in other specimens of Ipomoea. (Cf. Heitz 1926, $\mathrm{n}=14$ in $I$. Purga; Kano 1929, $\mathrm{n}=42$ (?) in I. edibilis.)

The PMC in this plant are extraordinally large in comparison with the external appearance, and especially the appearance of the flowers. On the contrary to this the first and second meiotic chromosomes are much smaller in comparison with the PMC.

Mina lobata has also 30 diploid number of chromosomes (Fig. 75).

\section{Apocynaceae}

There was no account of chromosome numbers in this family when we undertook to study the following three species. But recently Finn ('28) counted the number of chromosomes of Vinca and Margadant ('27) of Lochnera.

In the present work 4 species in 4 genera, were submitted for chromosome counts (cf. Table 1).

Lochnera rosea (Fig. 76). Somatic chromosomes in this plant are much longer and thicker than in the species hitherto studied. The meiotic number of chromosomes is 8 . (Margadent 1927, $\mathrm{n}=8$.)

\section{Gentianaceae}

In this family there are few records of exact chromosome counts, but we may mention the following among those already known (see the next table.)

Gentiana Makinoi (Fig. 80). Chromosome counts in the genus Gentiana have only been made by Stolt, as stated above. Since then there have been no further reports on the present genus. The materials being collected at Sugo-Norikosi in the province of Ettyû, were fixed by Farmer's fluid in the very place. The PMC as well as

\begin{tabular}{l|r|c|c}
\hline \multicolumn{1}{c|}{ Names of plant } & $\mathrm{n}$ & Author & \\
\hline Gentiana lutea & 21 & Stolt & 1921 \\
G. procera & ca. 40 & Denniston & 1913 \\
Leiphaimos azurea & 18 & Winge & 1925 \\
Cotylantera tenuis & $16-18$ & Oehler & 1927 \\
Voyria coerulea & $18-20$ &,$"$ &,$"$ \\
Leiphaimos spec. & $16-20$ &,$"$ &, \\
Voyriella parvifiora & $10-14$ &,$"$ & $"$
\end{tabular}
their meiotic chromosomes, 13, are much larger than those of the formerly reported species of Exacum (cf. Table 1). The cell volume of the PMC is also very much larger than that of Exacum; the chromosomes are likewise larger.

wisetonensis. IIM. 48. Solanum Capsicastrum. Somatic nuclear plate. 49. Nolana grandiflora. IA. 50. N. prostrata. IM. 51. N. tenella. IIM. 52. Nepeta Mussini. IM. 53. Mosla punctata. IM. 54. Salvia coccinea. IA. 55. S. farinacea. IA. 56. S. pratensis var. tenorii. IA. 57. S. argentea. IM. 58. S. patens. IA. 59. Callicarpa japonica. IIM. 60. Vitex trifolia var. ovata. IM. 61. Echium plantagineum. IA. 62. E. creticum. IM. 63. Anchusa italica. Somatic nuclear plate. 64. Phacelia campanularia. IM. 65. P. tanacetifolia. IM. 66. Nemophila Menziesii. IM. 67. Wigandia Vigieri. IIM. 


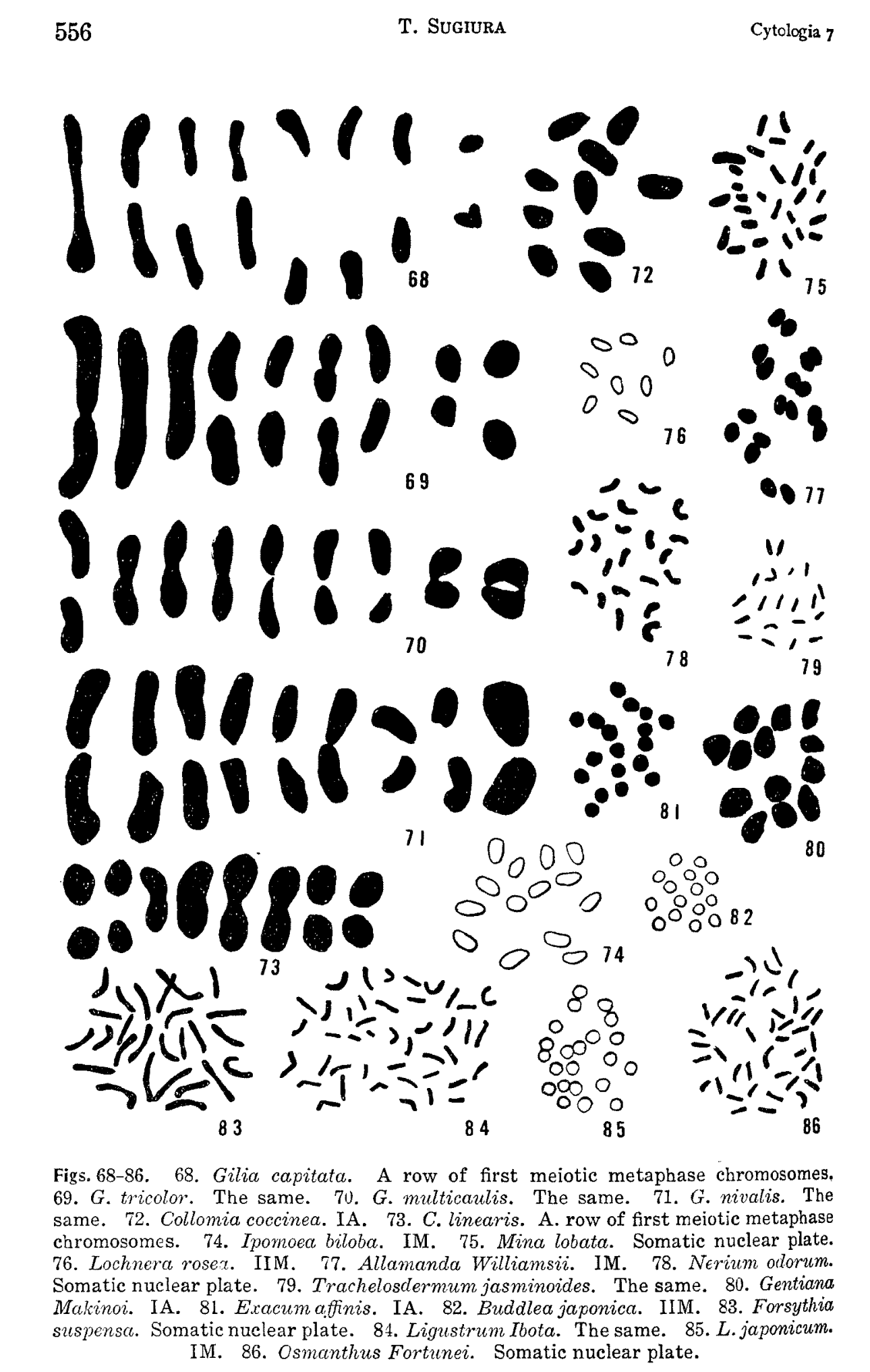




\section{Oleaceae}

According to Tischler (1927, '28, '31) only two genera Syringa and Forsythia were studied in for the chromosome count. In this paper the following 4 species in 3 genera are newly described (cf. Table 1).

Ligustrum japonicum (Fig. 85). $\mathrm{n}=22$. Some chromosome pairs are not arranged at the equatorial plate of metaphase, which is not due to their sliding down caused by the edge of a microtome knife during the cutting of the serial sections. Similar figures were also observed in Fatsia japonica.

\section{Staticeae}

Microsporogenetical investigations in this family have been unknown up to the present. Having studied 5 species of Statice and one species of Armeria, I deter$\min \epsilon \mathrm{d}$ the chromosome numbers to be 8 in former and 10 in the latter.

Statice sinuata (Fig. 89). Generally speaking the Statice and Armeria materials have a strong affinity for staining. At diaphase of $S$. sinuata there is noticed ones unequal pair of chromosomes which behaves as normal ones during meiosis. The heteromorphic nature of the unequal pair becomes indistinct at metaphase.

S. spicata (Fig. 90). This plant, in spite of its smaller external size, has relatively larger meiotic chromosomes in comparison with those of other species in the same genus. The second meiotic chromosomes quite resemble the somatic ones in having a thread-like shape. At diaphase there are two nucleoli which are never seen in the other three species. The size of the PMC is quite similar to that of $S$. sinuata and $S$. incana and the size of early tetrads in $S$. spicata is rather larger than those of $S$. sinuata. S. suworowii, $\mathrm{n}=8$ (Fig. 91).

Armeria vulgaris (Fig. 92). On account of the few flower buds available for study, good metaphase figures were not observed. But from the diaphase and interphase figures the meiotic number of chromosomes in this species is presumed as 10 .

\section{Primulaceae}

The counting of the chromosome numbers in Primula bas been done by several authors such as Gregory, Marchal, ete. According to the previous results, the meiotic chromosome numbers such as $9,12,18,24,27$, and $36(?)$ are known.

Primula Kewensis (Fig. 95). The meiotic number of chromosomes is 18. The meiotic chromosomes are almost of the same size as those of frondosa. (Newton and Pellew 1929, $2 \mathrm{n}=18,36$.

$P$. sinensis var. stellata (Fig. 94). $\mathrm{n}=12$. (Belling 1927, $\mathrm{n}=12$ in $P$. sinensis ; Haldane $1929, \mathrm{n}=24$ in $P$. sinensis var. gigas.)

\section{Myrsinaceae}

Ardisia crispa has 46 somatic chromosomes (Fig. 96). (Dahlgren $1916, \mathrm{n}=23$.) 


\section{Cornaceae}

As to the chromosome numbers in this family, there are few records published: Cornus candidissima, C. glaberata (Winge 1917), Aucuba japonica (Palm and Rutgers 1917, Sakamura 1916, Sugiura 1927, Meurman 1929 and Sinotô 1929). We have studied Aucuba and Macrocarpium.

Macrocarpinium officinale, $\mathrm{n}=18$ (Fig. 97).

\section{Umbelliferae}

Recently Schulz-Gaebel (1930) has studied a lot of umbelliferous plants and determined their chromosome numbers. Ogawa (1929), Melderis (1930) and Wanscher (1931-3) also counted chromosome numbers in this family.

Didiscus coeruleus (Fig. 98). $\mathrm{n}=11$. (Wanscher 1933, $\mathrm{n}=22$.)

\section{Araliaceae}

There are few karyological descriptions of chromosome numbers in this family. Formerly the somatic numbers of chromosomes in Hedera helix var. typica and $H$. conglomerata were counted to be 44 or 46 by Oehm (1924), who also showed that the nuclear plates of $H$. helix var. hibernica have 88 , but not more than 98 . Wanscher (1933) also counted some chromosome numbers in this family.

Fatsia japonica (Fig. 99). The meiotic chromosomes are rather small and spherical. Their number is 24. Although the chromosome behavior during meiosis is normal, it is sometimes observed that at metaphase the chromosomes do not advance to both poles simultaneously as in the case of other trees (Aucuba, Myrica, Ligustrum, etc.). (Wanscher $1933,2 \mathrm{n}=24$.)

Panax japonicum f. typicum (Fig. 100). This plant being closely related to $P$. Ginseng is also herbaceous and itsheight is about 2 feet. It has 22 meiotic chromosomes.

Considering Oehm's result for Hedera in Schefflereae and my own count for Panax in Aralieae, it seems that the chromosome number 22 is common to both sections. (Wanscher 1933, $\mathrm{n}=24$ in two species of Panax.)

\section{Oenotheraceae}

Gaura Lindheimeri (Fig. 101) has 7 meiotic chromosomes which has no connected ring at prophase as in some forms of Oenothera. The meiotic chromosomes are much smaller in comparison with the PMC in which they are contained.

\section{Lythraceae}

Formerly the meiotic chromosome numbers in this family were counted by Tischler in Lythrum hyssopifolium and salicaria, by Shinke in $L$. salicaria var. genuina and found to be 10,25 , and 15 respectively. But there were still no counts of meiotic chromosomes in Cuphea. 
Cuphea miniata (Fig. 105). The size of the first meiotic chromosomes (9) is rather various as shown here. But there is no increase or decrease of staining power compared with Pristiurus (Rükert).

It is interesting to observe that there are two chromosomes at the centre of the chromosome ring which consists of the remaining 7 in the first meiotic division, while there is one in the chromosome ring in the second division.

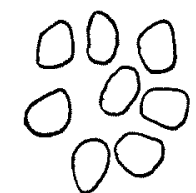

87

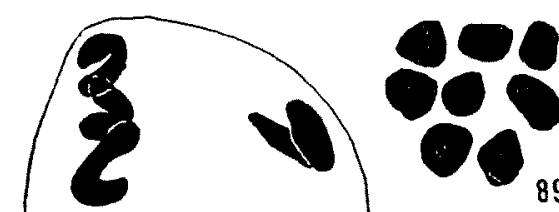

89

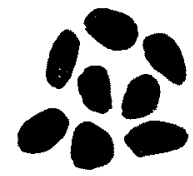

90
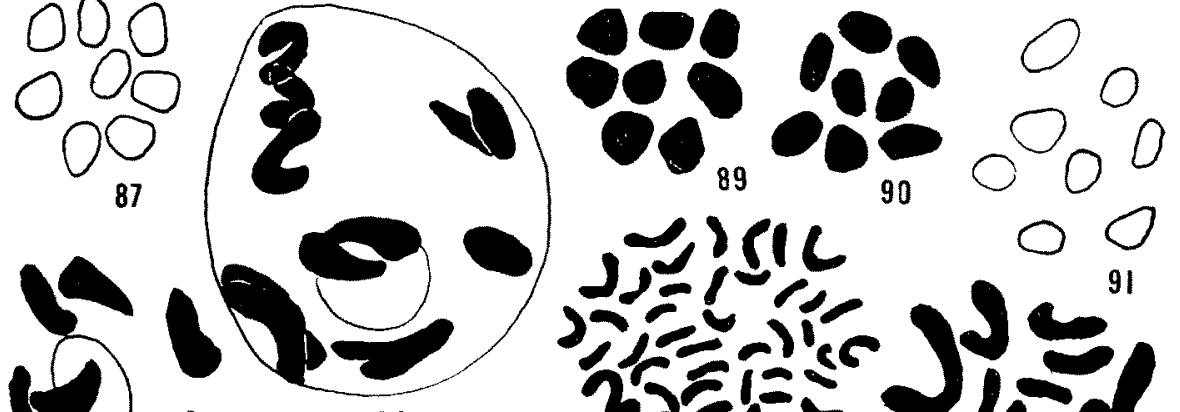

Jic $\circ 0$

88

0

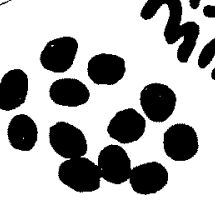

92
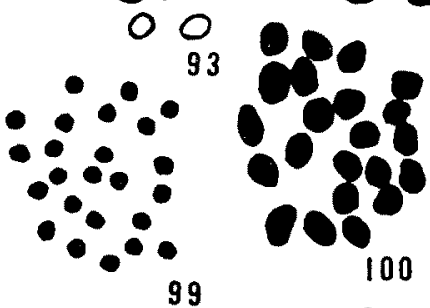

100

94
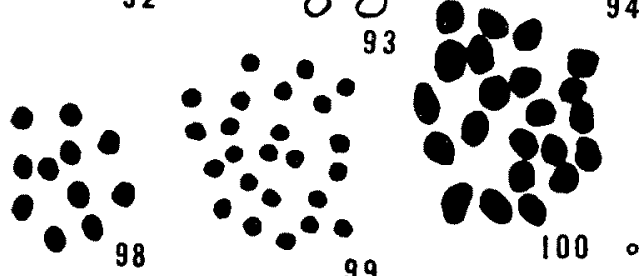

99
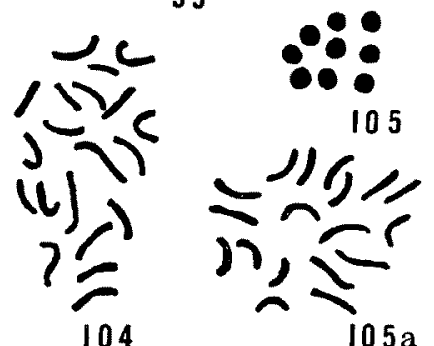

$105 a$

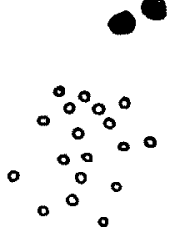

- 95
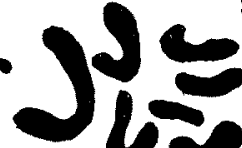

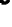

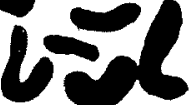

96
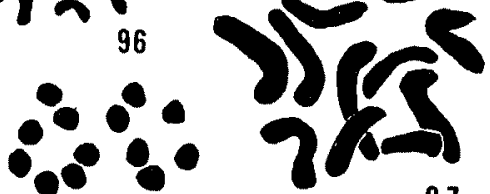

97

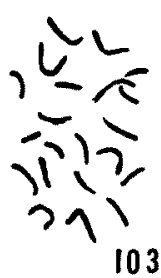

104
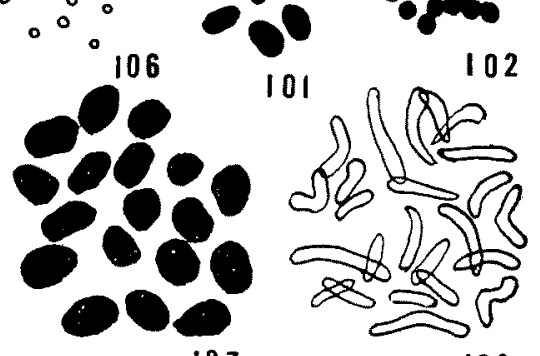

107

108

Figs. 81-108. 87. Statice incana. IM. 88. S. latifolia. Diaphase. 89. S. sinuata. 1M. 90. S. spicata. IM. 91. S. Suworowii. IA. 92. Armeria vulgaris. Interphase (polar view). 93. Primula frondosa. IM. 94. $P$. sinensis var. stellata. IIM. 95. $P$. Kewensis. IM. 96. Ardisia crispa. Somatic nuclear plate. 97. Macrocarpium officinale. The same. 98. Didiscus coeruleus. IM. 99. Fatsia japonica. IM. 100. Panax japonicum f. typicum. IIM. 101. Gaura Lindheimeri. IM. 102. Melastoma candidum. IM. 103. Eucalyptus globulus. 104. E. citriodora. Somatic nuclear plate. 105. Cuphea miniata. IIM. 105 a. ditto. Somatic nuclear plate. 1C6. C. platycentra. IM. 107. Edzgeworthia papyrifera. IM. 108. Epiphyllum truncatum. 


\section{Thymelaeaceae}

The chromosome counts in this family are very few in spite of there being about 500 species known.

Edzgeworthia papyrifera (Fig. 107). It is often observed during the first metaphase that there are connections between two chromosomes which is considered to be related to tetraploidy. In the diaphase there are seen so-called tetravalent figures which seems to show the autoploid doubling of the chromosomes in this plant.

\section{Cactaceae}

As to the number of chromosomes in various species in this family, there were no accounts until Ishii's karyological study of Mammillaria $\mathrm{sp}$. was published (1929). The writer has already studied the number of chromosomes in several species, as follows: Epiphyllum truncatum $(2 \mathrm{n}=24)$ (Fig. 108), Mamillaria glochidiata $(2 \mathrm{n}=24)($ Fig. 109) and $M$. sp. $(2 \mathrm{n}=24)$ (Fig. 110).

For material root-tip-cells were chosen. The chromosomes are rather larger than those of Myrtaceae. In the egg cell of Mammillaria we found Golgi apparatus.

Ishii (1929) and Jaretzky (1929) counted the meiotic number of chromosomes of Mammitlaria sp. and M.centricirrha to be 11 in both cases. Quite recently Stockwell (1935) counted somatic numbers of chromosomes in 17 species.

\section{Laasaceae}

Blumenbachia hieronymi (Fig. 111). Meiotic chromosomes, 12, have heterogeneous forms, some of which often proceed ahead to both poles.

\section{Guttiferae}

In this family, the genus Hypericum has been studied karyologically by many authors including Chattaway (1926), Nielsen (1924) and Winge (1925). Considering the numbers of chromosomes as determined by them, it suggests Carex type; namely 7, $8,9,10,16,20$. We have now found the number of ehromosomes in $H$. patulum to be 18 which fills the gap between 16 and 20 .

Hypericum patulum (Figs. 114-114a). In archesporial cells cubic chromosomes $(0.6 \mu \times 0.5 \mu)$ were observed as shown in Fig. 114a. This shape of chromosomes has only rarely been recorded. Quite recently Hoar and Haertl (1932) counted the meiotic number of chromosomes in several species of Hypericum to be 8, 9, 12, 16 and 19. So the chromosome numbers now known in this genus are 7, 8, 9, 10, 12, 16, 18, 19 and 20.

\section{Sterculiaceae}

Previously only the meiotic chromosome number in Theobroma Cacao in Buettnerieae was counted to be 8 by Knijper (1914) and Cheesman (1927).

Firmiana platanifolia (Fig. 115). This species in Sterculieae has 16 meiotic chromosome number. 


\section{Malvaceae}

Much of our information to the chromosome number in this family is due to the contributions of Cannot (1930), Hikolajewa (1933), Denham (1924), Youngman (1927), Zaitzew (1927), Beal (1928), Banerji (1929) on Gossypium, Svensson-Stenar (1925b) on Lavatera, Malva and Malvastrum; Youngman (1927) on Hibiscus and Thespesia; Tjebbes (1928) on Sidalcea; Kuhn (1930) on Abutilon. Accounts on three other plants are given here.

Althaea rosea (Fig. 117). $\mathrm{n}=28$. The hetero- and homotypic chromosomes are very small in comparison with the volume of the PMC, i.e. the chromosome at IM is $0.7 \mu \times 1 \mu$, while the diameter of PMC is $33 \mu$. As to the cytokinesis in Althaea, it has been observed variously by several investigators. Wimmel (1850) observed the division by cell plates. On the other hand, von Mohl (1853) figured the division by constriction accompanied sometimes or not by cell-plate. The present writer however, found no cell-plates or their provisional ones, but only protoplasmic furrows. In 1854 Pringsheim studied the bipartition and quadripartition in pollen formation, saying that in Althaea there was a quadripartition either monoplanal or tetrahedral and figured a monoplanal square in the centre. Our observations on these points agree with his. In addition to the above we observed that one of the early tetrads stands out at one side, forming a monoplanal arrangement. As to the central square, it is not worth mentioning here as Farr (1916) described it in Nicotiana. This phenomena of a central square area seems to be rather seldom, as in my present study no cases were found except in Malvaceae. Denham (1924) also observed this central square area in Gossypium.

Quite recently Kesseler (1932) reported that " The most favourable period for obtaining the desired meiotic stages in Althaea is during the night, i.e. from 8 P.M. to 6 A.M. I found no division figures at all after 6 A.M." But in my study it is not always so. We collected flower buds in the daytime, from 10 A.M. to 3 P.M., and got satisfactory results. Kesseler's count of meiotic chromosomes in this plant is 21 . Thus it seems that there are several different chromosome numbers according to the form of this plant.

Abutilon Avicennae (Fig. 116). The meiotic chromosomes are much smaller, while the pollen mother cells in which they are contained, are large $(21 \mu$ in diameter at IM, $25 \times 21 \mu$ at IIM). (Kuhn 1930, $2 \mathrm{n}=16$ in A. striatum "Thompsoni " and "Souvenir de Bonne ".)

Lavatera (Svensson-Stenar 1925, $\mathrm{n}=20$ in L. thuringiaca).

L. trimestris (Figs. 118, 118a). The PMC are extremely large as in the case of $L$. thuringiaca (ca. $40 \mu \times 34 \mu$ at IIM). The meiotic chromosomes are much larger than those of Althaea. In the heterotypic anaphase small granules which were previously dispersed throughout the cytoplasm come together and enclose anaphae chromosomes which condition continues to the next division. The same phenomenon (perinu- 
clear zone) was also observed in Hibiscus (Youngman, 1927), Carica (Sugiura, 1927), etc. Somatic chromosomes are rather thick rods, some of which are crooked (Fig. 118a). Tetrahedral or monoplanal quadripartition by furrowing is found in this plant. A central square is ofren found.

\section{Celastraceae}

Euonymus japonica (Fig. 124). Only root-tip cells were studied. The somatic chromosomes being very fine rods, are very different from those of Sapindaceae and Aquifoliaceae. The chromosome number is 32 . (Morinaga and Fukushima 1931, $\mathrm{n}=16$.)

\section{Anacardiaceae}

So far as $I$ know, the chromosome number in this family is only to be found in Grimm's paper (1912). According to him the meiotic chromosome number in Rhus Toxicodron is 15 .

Rhus succedanea. $2 \mathrm{n}=30$ (Fig. 126).

\section{Limnanthaceae}

As far as I know, Stenar (1925) was the first to study Limnanthes Douglasii karyologically ; after his counts the meiotic chromosome number is 5 .

Limnanthes Douglasii (Fig. 127). The meiotic chromosomes, being large in comparison with the external appearance of the plant, were 5 in number as in the case of Stenar's count. They are more rectangular than spherical. Meiotic chromosomes at IM as well as at IIM are almost of the same size. It seems that this family is rather isolated from the neighbouring families from the karyological point of view.

\section{Euphorbiaceae}

Genera in this family have been studied karyologically by several authors;

Mercurialis (Strasburger 1910, Yampolsky 1925), Ricinus (Němec 1910a, Suessenguth and Taylor 1926), Euphorbia (Malte 1908, Carano 1915, Weniger 1917, Modilewski 1910, Němec 1910, Harrison 1930) and Daphniphyllum (Sinotô 1928 , 1929b, Sugiura 1928). Among them Němec, Suessenguth and Taylor connted the somatic chromosomes of Ricinus to be 20 .

Ricinus. The present writer also, having studied Ricinus sanguineus and gibsoni, determined the number of meiotic chromosomes in the former to be 10 (Fig. 129) and the somatic ones in the latter to be 20 (Fig. 130). The chromomere structure was observed in synaptic as well as open spirem stages. The chromomeres are not disc shaped but granules, which are buried in linin threads. A similar situation was also observed in living materials (cf. Bělař's "Die Cytologischen Grundlagen der Vererbung" 1928). The somatic chromosomes in gibsoni are short rods, some of them slightly bent. 
Euphorbia splendens (Fig. 128). 18 meiotic chromosomes are found. (Weniger 1917, $n=12$; Harrison 1930, $2 n=40$.)

Mallotus japonicus (Fig. 131). Although this species is dioecious, there are no heterochromosomes to be found. The meiotic chromosomes, 36 , are all of equal spherical shape.

\section{Rutaceae}

Studies of the chromosome number in this family are rather few. Genera which have been studied are Erythrochiton (Heitz|1926), Triphasia, Aeglopsis, Fortunella, Poincirus, Soverinia (Longley 1925), Citrus (Longley 1925, Frost 1925, Nakamura Oppenheimer and Fraenkel 1929), Ruta (Cappelletti 1929a, b) and Xanthoxylum (Sinotô 1929).

Among these the Citrus has been most studied. According to Frost's and Longley's studies the meiotic chromosome number in Citrus is exclusively 9 or 18 .

Citrus. I have studied the five species and counted the somatic number of chromosomes in root-tip cells to be 18 exclusively. The somatic chromosomes of $C$. Aurantium, subsp. nobilis var. Tachibana are rather finer than those of the other two species (Fig. 124). (Longley and Frost 1925, $\mathrm{n}=9$ in C. nobilis; Strasburger $1907 \mathrm{n}=8$ in $C$. Aurantium subsp. amara; Osawa 1912, $\mathrm{n}=8$ in C. Aurantium subsp. nobilis var. "Unshu"; Nakamura 1929, $\mathrm{n}=9$ in C. nobilis "Fujii Wase".) But these numbers counted by Strasburger and Osawa seem to be erroneous, as Tischler wrote in his "Pflanzliche ChromosomenZahlen" (1927). At any rate the basic number in Citrus seems to be 9. In the somatic metaphase of C. Decumana (Fig. 136) a nucleolar remnant was observed (cf. Tahara in Helianthus 1915; Yamaha and Sinotô in various higher plants 1925).

\section{Lynaceae}

Linum grandiflorum (Fig. 138). The somatic chromosomes are 16 in number, being thick rods. (Kikuchi 1926, $\mathrm{n}=9$; Nikolajewa and Martzenitzina 1927, $2 \mathrm{n}=16$; de Vilmorin et Simonet 1927, $\mathrm{n}=8$ ).

\section{Tropaeolaceae}

Even though the nasturtium is so commoly cultivated in both Europe and North America, karyological observations about it are, on the contrary, so few that the writer has attempted its karyological studies since 1923. Karyological studies of Tropaeolum majus and T. perigrinum were published respectively in 1925 and 1928. We describe here our studies of Tropaeolum since 1928. The materials used were all taken from plants raised from the seeds of Sutton Company. They are:-

A) Tall varieties : Brilliant, Dark crimson, Lucifer, Black Prince, Rosy Queen, Pearl and Yellow.

B) Dwarf varieties (T. majus nanum): Yellow, Salmon Pink, Scarlet Queen, Cloth of Gold, Sunset. Empress of India, The nymph, The king of Thom Thumb, Aurora, Ruby King, Coeruleum roseum, and King Theodore.

Among the tall varieties, Rosy Queen, Brilliant, Black Prince, and Lucifer are peltophorum varieties which are marked by pubescence on stems, foliage and flowers. 

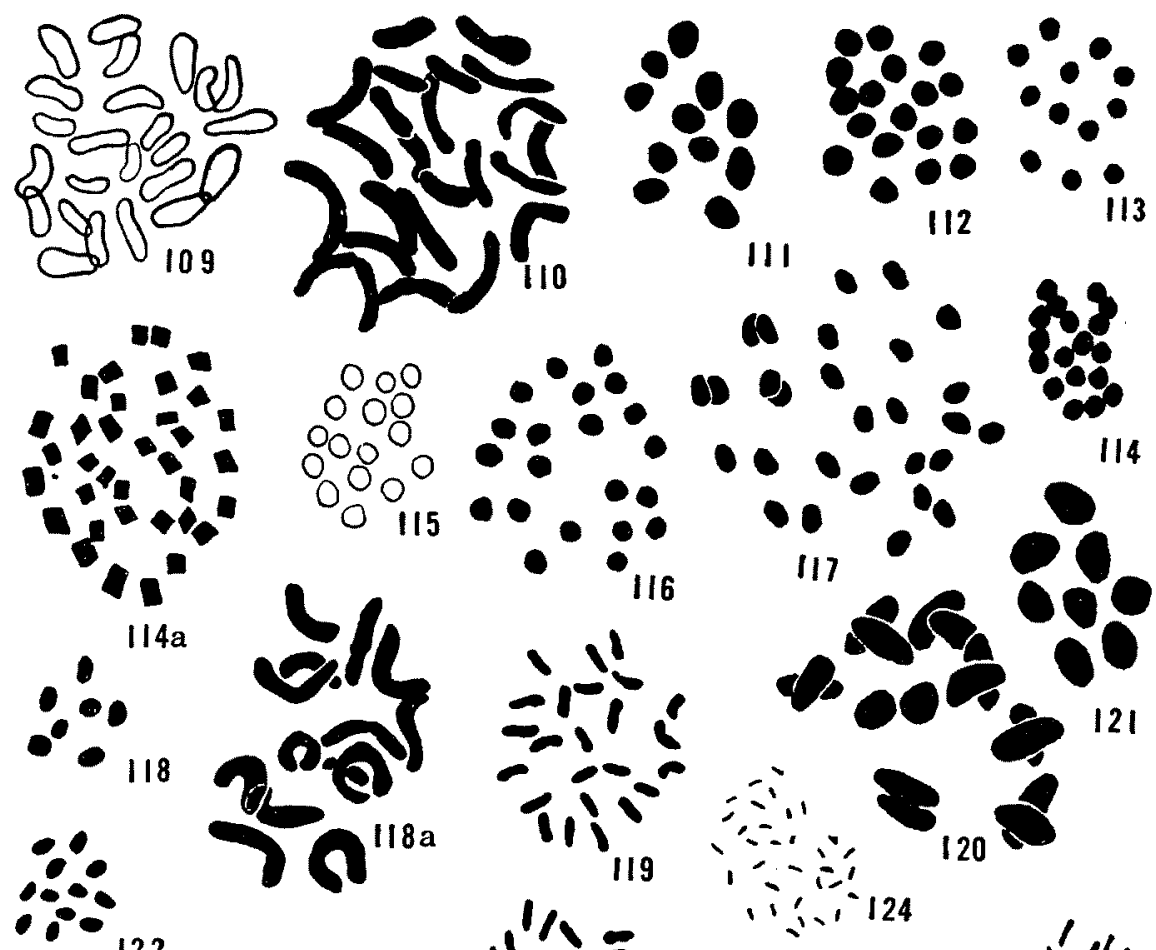

\section{III}

112
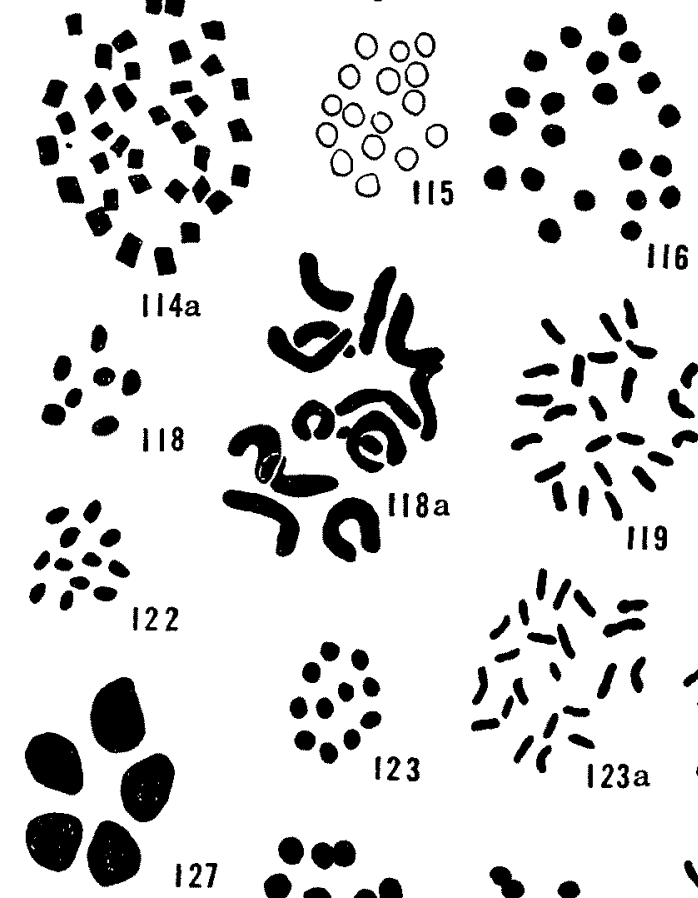

$\begin{array}{lll}0 & 0 & 0 \\ 0 & 0 & 0 \\ 0 & 0 & 0\end{array}$

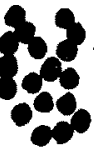

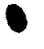
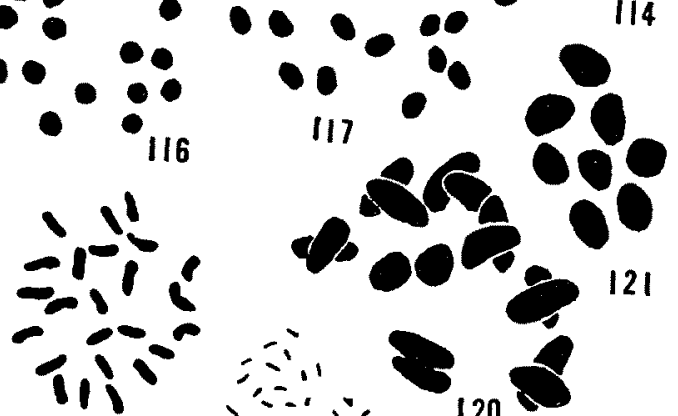
119
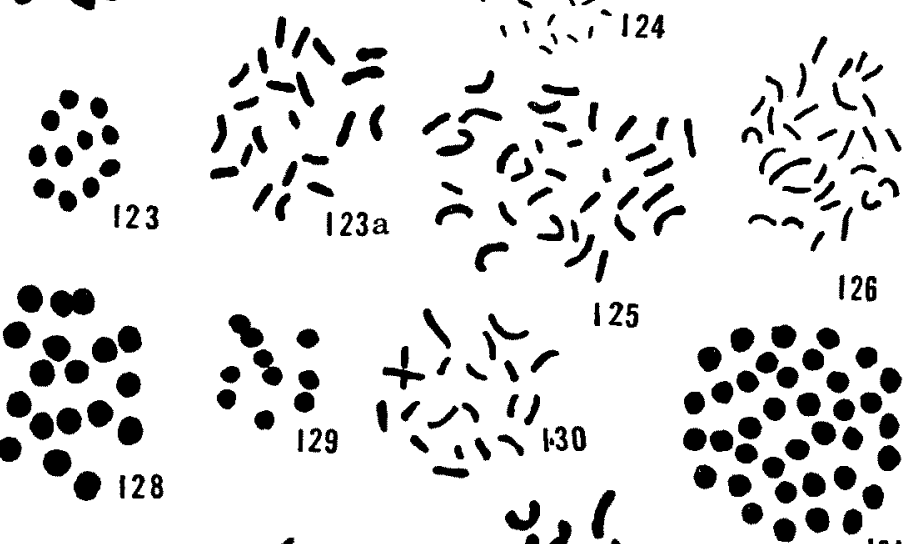

125

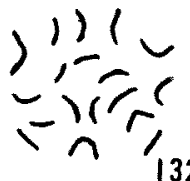
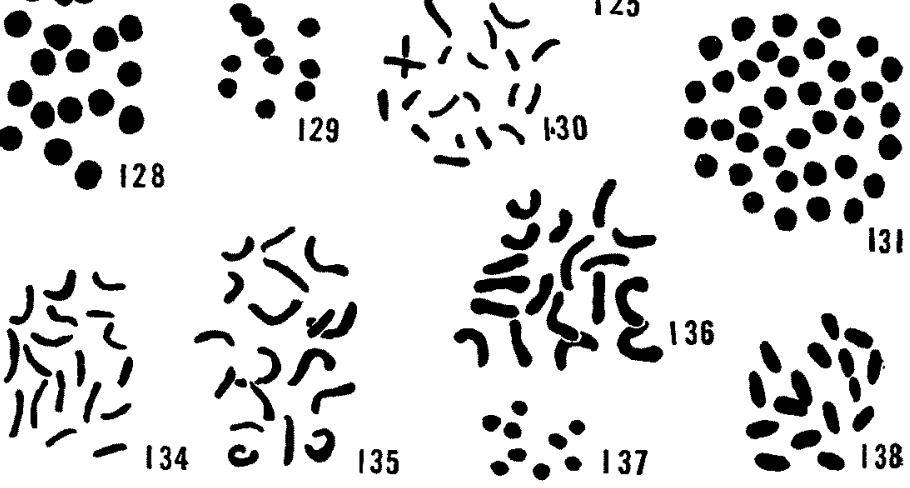

135

Figs. 109-138. 109. Mammillaria glochidiata. Somatic nuclear plate. 110. Mammillaria sp. The same. 111. Blumenbachia hieronymi. IM. 112. Mentzelia Lindleyi. IA. 113. Loasa aurantiaca. IA. 114. Hypericum patulum. IA. 114 a. ditto. Chromosomes in an archesporial cell. 115. Firmiana platanifolia. IIM. 116. Abutilon Avicennae. IM. 117. Althaea rosea. IM. 118. Lavatera trimestris. IA. 118 a. ditto. Somatic chromosomes. 119. Hovenia duleis. The same. 120. Impatiens Sultani. IM. 121. I. Holstii. IA. 122. Sabia japonica. IIM. 123. Cardiospermum Halicacabum. 
A) Meiotic Chromosomes. The size of some of the meiotic chromosomes in tall varieties, including peltophorum, is somewhat larger than in the dwarf ones as shown in Figs. 139a, b. The shape of meiotic chromosomes is somewhat spherical at metaphase and ellipsoidal at anaphase. In spite of there being different external characters among varieties of majus and peltophorum, the number of meiotic chromosomes is 14 . The meiotic number of chromosomes in $T$. majus was first reported by the present writer and later confirmed by Heitz, Winge (1925) and Bolenbaugh (1928). The meiotic number in peltophorum varieties is also 14, though Heitz (1926) thought it might be 14. The size of meiotic chromosomes in peltophorum is rather larger than in majus.

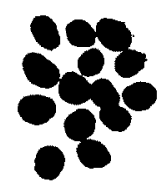

139 a

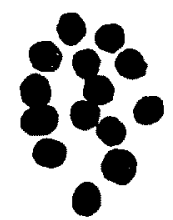

$139 \mathrm{~b}$

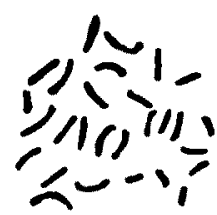

$140 \mathrm{a}$

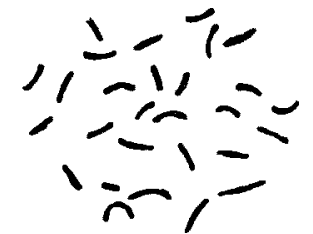

$140 \mathrm{~b}$

Figs. 139-140. 139 a. Tropaeolum majus Aurora. Meiotic chromosomes (mostly anaphasial). b. T. peltophorum. 140. T. majus. Somatic chromosomes in root-tip cells. a. Cloth of Gold. b. Scarlet Queen.

B) Somatic Chromosomes (Figs. 140a, b) are narrow-shaped, some are short and some are long. In some varieties there are chromosomes which are three times thicker than the others. The number is 28 in all varieties examined. The pairing of the somatic chromosomes is observed in every variety investigated, as in Kuwada's study of Oryza sativa, etc. Size and shape-difference among varieties is more or less to be seen; viz. long and short rod chromosomes (Coeruleum, roseum, King Theodore, Ladybird), V-shaped chromosomes (Nymph, Ruby King, Scarlet Queen, Lucifer), more or less constricted chromosomes (Black Prince), V- and constricted chromosomes (Yellow Tall), long constricted chromosomes (Pearl Tall), etc.

Tropaeolum tuberosum (Fig. 141). Originally grown in Peru, it has edible ground tubers 2-3 inches long. Somatic chromosomes are long narrow rods. From this we consider that the basic number in the genus Tropaeolum should be 7, as later investigation will probably show.

IIA. 123 a. ditto. Somatic chromosomes. 124. Euonymus japonica. The same. 125. Ilex crenata. The same. 126. Rhus succedanea. Somatic nuclear plate. 127. Limnanthes Dougla:ii. IIM. 128. Euphorbia splendens. IM. 129. Ricinus sanguineus. IA. 130. R. gibsoni. Somatic nuclear plate. 131. Mallotus japonicus. IIM. 132. Citrus Aurantium subsp. Juno. Somatic nuclear plate. 133. C. Aurantium subsp. nobilis var. japonica. Somatic chromosomes. 134. C. Aurantium subsp. nobilis var. Tachibana. The same. 135. C. Aurantium subsp. amara. The same. 136. C. Decumana. Somatic nuclear plate. 137. Boennighausenia japonica. IM. 138. Linum grandiflorum. Somatic chromosomes. 


\section{Geraniaceae}

The number of chromosomes in this family was first counted by Heitz in the Geranium and Erodium (1926). In 1928 Tjebbes also determined them in G. pratense. In 1928 Takagi studied the numbers of chromosomes among species of Pelargonium. The studies of these writers show that polyploidy exists in this family.

\section{Pelargonium}

Our karyological knowledge of the plants in this genus is due largely to Takagi's work (1928). According to her there are 16, 18, 36, 45, 81, and 90 somatic chromosomes in this genus.

Pelargonium zonale (Fig. 142). According to Takagi (1928), the somatic number of chromosomes in $P$. zonale is 36 , while that of $P$. inquinans and hortrum is 18 . These three species belong to the section Ciconium. But my present investigation shows that the somatic number of chromosomes in $P$. zonale is 18 and that they are rather various in length.

P. zonale var. Sankonishiki (Fig. 143). There is an interesting figure observable in the homeotypic anaphase. In this plant it is sometimes found that both homeotypic spindle fibres are somewhat loosen instead of taut. The first cleavage furrow will appear during the homeotypic metaphase.

\section{Leguminosae}

Though the karyological studies in this family were began early in this century, the study of the chromosome numbers of many plants of this family has been carried out only in the past few years. The full list of chromosome numbers in this family was published by Kawakami (1930).

In the present work the writer determined the somatic chromosome numbers of 5 species in 5 genera (cf. Table 1).

\section{Rosaceae}

This family has been already extensively studied cytologically and many important works have been published by various investigators, viz, Rosa (Taeckholm 192022, Blackburn and Harrison 1921-24), Crataegus, Rubus, Fragaria (Longley 1924), Prunus (Kobel 1927, Okabe 1928), etc. We have studied 4 forms, viz. Cydonia sinensis, Raphilolepsis umbeliata var. mertensii, Cotoneaster rotundifolia and Kearia japonica, the materials of which are exclusively root-tip-cells.

Cydonia sinensis (Fig. 149). $2 \mathrm{n}=16$. Other species of Cydonia previously studied had 17 meiotic chromosomes (Kobel 1927, Morinaga 1929).

\section{Hamamelidaceae}

The chromosome numbers in this family has not been known yet.

Distylium racemosum (Fig. 153). The meiotic chromosomes are narrow rod-shaped during the first metaphase. Such a case is rarely known except Gilia, although it is occasionally found during the second division in some species. 


\section{Crassulaceae}

Quite recently (1935) Baldwin counted the somatic numbers of chromosomes in 16 species of Sedum. In consideration of his counts and mine (cf. Table 1), it becomes to be evident that the basic number of chromosomes in this genus is 12 .

\section{Capparidaceae}

Previously Tischler (1921-22), Taylor (1925) and Ufer (1927) have investigated several species in the genus Cleome and found various numbers, i.e., Cleome paradoxa (16 Tischler), C. spinosa (19 Taylor), C. spinosa ((9)-10 Ufer), C. sp. var. gigas (ca. 18-20 Ufer), C. gigantea (ca. 35 Ufer), C. gig. var. gigas (ca. 70 Ufer).

In Cleome spinosa there has been different numbers of meiotic chromosomes to be counted by Taylor and Ufer as enumerated above. My chromosome count in this species, however, does not coincide with them; it is 12 .

\section{Saxifragaceae}

According to Tischler's list of chromosome numbers (1927), there wtre only 5 genera and 12 species. But after 4 years the plants in Tischler's list (1931) were enormously increased; about 14 genera and 82 species having been added to the list. Studies on Saxifraga (Schoennagel 1930), Heuchera, Hydrangea, Fibes (Tischler 1927, Meurman '28) and Philadelphus (Bengham 1930) have been energetically pursued.

Hydrangea virens (Fig. 154). According to the results previously obtained, the meiotic number of chromosomes in this genus is 18 , though they were mostly counted in the somatic cells. In this plant we found 18 meiotic chromosomes. (Morinaga et alii 1929, $\mathrm{n}=18$ in H. opuloides ; Schoennagel $1931,2 \mathrm{n}=36$ in $H$. aspera, and $H$. radiata). Thus from the former results the basic number in the Hydrangea is probably 18.

\section{Papaveraceae}

In Tischler's “Pflanzliche Chromosomen-Zahlen (1927)" only 5 genera and 21 species were listed, and although 4 years have elapsed since that time only the single species Corydalis cava has been added to the list. We now add to the above list the following 6 genera and 9 species; namely, Papaver glaucum, P. pavonium, P. Rupifragum, Argemone grandiflora, P. umbrosum, Platystemon californicus, Hunnemannia fumariaefolia, Pteridophyllum racemosum, Chelidonium majus and Glaucium flavum.

\section{Papaver}

Plants belonging to this genus were first investigated karyologically some years ago by Tahara (1915). Tahara counted the meiotic numbers of chromosomes in $P$. Rhoeas and $P$. dominuferum to be 7 and 11 respectively. Since that time Ljungdahl aud Yasui have counted 7, 14, 35, 21, 22 meiotic chromosomes in this genus. But still there appears no meiotic number 6 . We found it in $P$. pavonium in 1929 and also in $P$. apulum this year. The meiotic chromosome numbers 12 is also found in $P$. pinnatifolia. Generally meiotic and somatic chromosomes of Papaver are large in comparison with their cell size as in Primula, etc. 
Papaver glaucum (Fig. 163). This has a dazzling scarlet flowers, the 2 petals being spotted at their base. It has 7 meiotic chromosomes
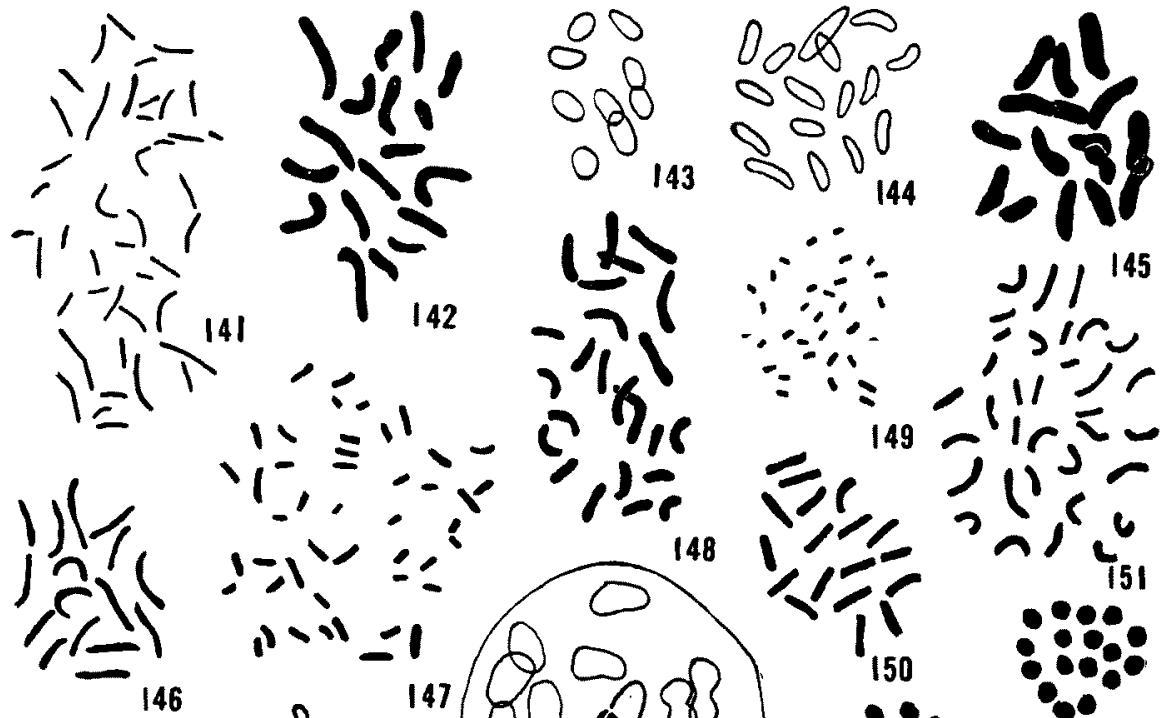

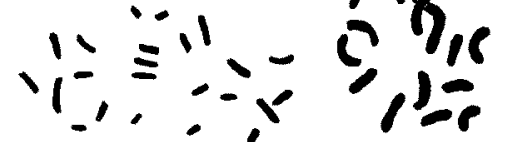
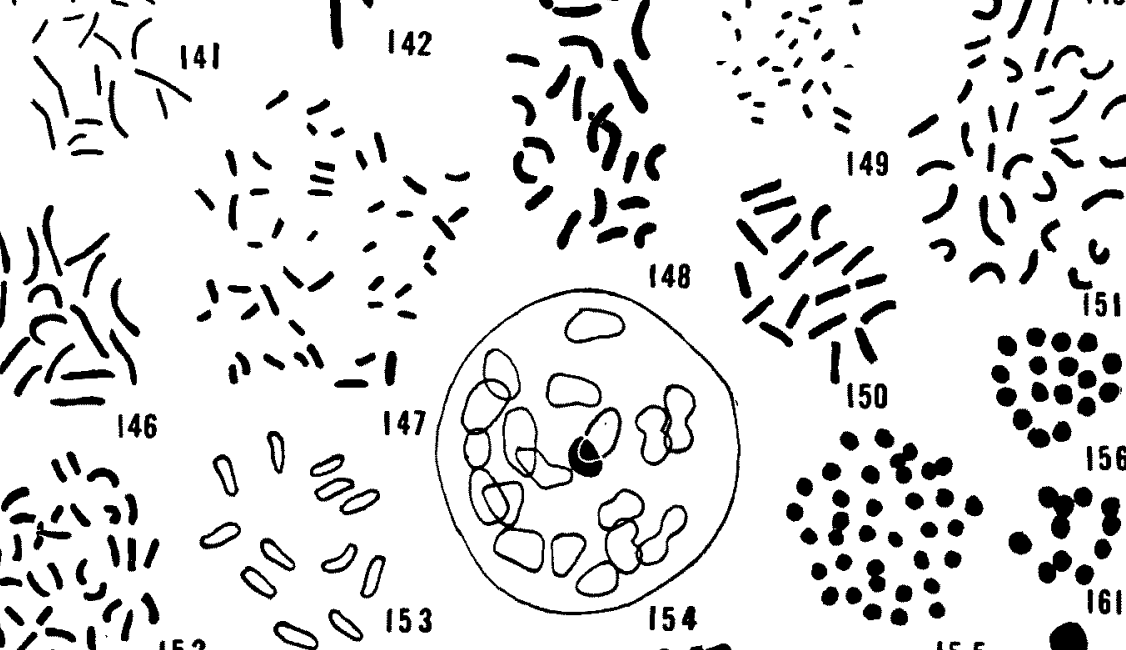

147
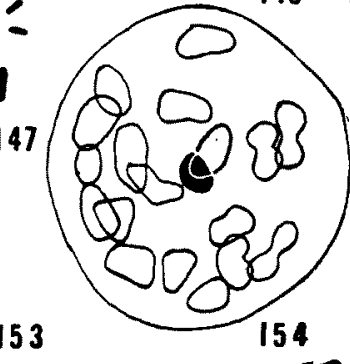

154

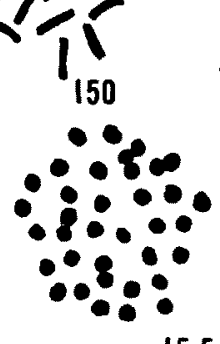

00

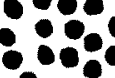

0

156

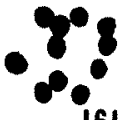

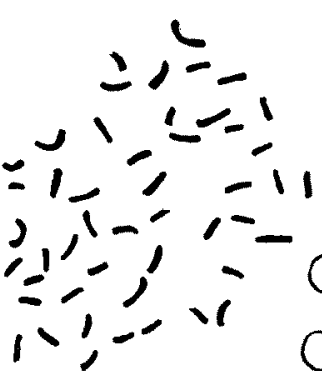

157

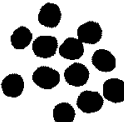

158
155
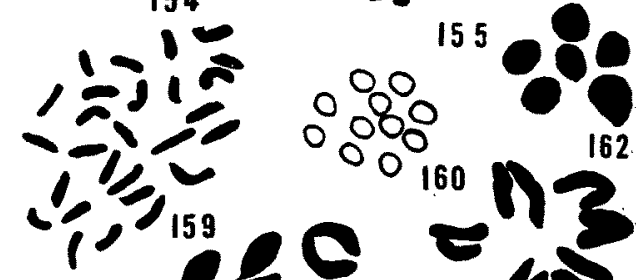

165<smiles>O=PO</smiles>

163

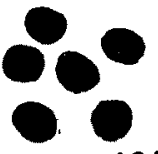

164
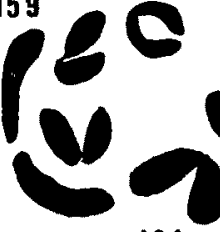

$164 \mathrm{a}$

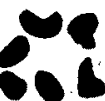

166.

Figs. 141-166. 141. Tropaeolum tuberosum. Somatic chromosomes. 142. Pelargonium zonalle. The same. 143. P. zonalle var. Sankonishiki. IIM. 144. Astragalus sinicus. Somatic chromosomes. 145. Cassia dimidiata. The same. 146. Indigofera pseudotinctoria. The same. 147. Cystisus scoparius. The same. 148. Acacia lophantha. The same. 149. Cydonia sinensis. The same. 150. Kearia japonica. The same. 151. Raphiolepsis umbellata var. mertensii. The same. 152. Cotoneaster rotundifolia. The same. 153. Distylium racemosum. IM. 154. Hydrangea virens. Diaphase. 155. H. paniculata var. floribunda. IM. 156. Kalanchoe globulifera. IM. 157. Sedum alboroseum. Somatic nuclear plate. 158. S. Twarenge. IM. 159. Eutrema Wasabi. Somatic nuclear plate. 160. Cleome monophylla. IM. 161. C. gurveoleus. IM. 162. Papaver apulum. IIM. 163. P. glaucum. IM. 164. P. pavonium. IM. 164 a. ditto. Diaphase. 165. P. pinnatifolia. IIM. 166. P. Rupifragum. IA. 
of equal size, in the diaphase no significant larger pair of chromosomes being seen. There are no size differences in the meiotic chromosomes between $P$. glaucum and pavonium.

P. pavonium (Fig. 164). It has vivid scarlet flowers with a broad purplish black band. The meiotic number of chromosomes is 6 as stated above. In the diaphase a special pair of chromosomes which is about twice longer than the others was observed, while in the same stage of glaucum no such pairs were found. Thus from the fact that a special long pair of chromosomes is found in the diaphase of pavonium species which has 6 meiotic chromosomes, one may suggest that two of the seven pairs of meiotic chromosomes fuse together thus making six in all. It is to be noted that the fused chromosomes are found only at diaphase, there being no such evidence in other phases. There is observed the furrowing process beginning early during interphase.

P. umbrosum (Fig. 167). It has bright crimson flowers with distinct black spots on each petal. These black spots are about twice larger than those of glaucum. The first and second meiotic chromosomes, being spherical, are rather larger than those of glaucum and pavonium, though umbrosum is smaller than glaucum in external appearance. The meiotic number of chromosomes is 7 . There are no different shaped gemini to be found at diaphase. Generally according to our investigation in Papaver, the size differences of chromosomes between first and second meiosis are relatively small.

P. Rupifragum (Fig. 166). This material was also obtained from seed acquired from the Musée d'Histoire Naturelle, Paris. It has small cream flowers. The PMC are rather large. The meiotic chromosomes are smaller than those of the other papavers I have studied. It is interesting to see that in this plant the meiotic chromosome arrangement in both the first and second divisions, is not the usual form, i.e. five making a circle with one in center, but a circle of all 6 chromosomes which is said to be less stable (cf. Kuwada 1929).

P. apulum (Fig. 162). One meiotic chromosome out of six is about twice as large as the remaining ones. (Cf. $P$. pavonium.)

P. pinnatifolia (Fig. 165) has 12 haploid chromosomes. The second meiotic chromosomes are narrow rod-shaped forming secondary association suggesting the chromosome doubling.

\begin{tabular}{|c|c|c|c|}
\hline$n=6$ & $\mathrm{n}=7$ & $\mathrm{n}=11$ & $\mathrm{n}=12$ \\
\hline $\begin{array}{l}\text { P. pavonium } \\
P . \text { apulum } \\
P . \text { Rupifragum }\end{array}$ & $\begin{array}{l}P . \text { umbrosum, P. atlanticum, } P . \\
\text { latericum, } P . \text { Persicum, } P \text {. tauri- } \\
\text { colum, } P . \text { hybridum, } P . \text { nudicaule, } \\
P . \text { alpinum, P. Rhoeas, } P \text {.pilosum, } \\
P . \text { dubium, P. Orientale, P. Stria- } \\
\text { tocarpum, } P \text {. radicaum }\end{array}$ & P. sominiferum & $P$. pinnatifolia \\
\hline
\end{tabular}


Referring to the previous results of the chromosome count in Papaver, we now know that there are four groups in this genus, namely $6,7,11$ and 12. (See the table in p. 569.)

Chelidonium majus (Figs. 172, 172a). The present material was sent from Musée d'Histoire Naturelle, Paris. The first meiotic chromosomes are more or less spherical while those of the second division are, on the contrary, filar in form. The latter figures of the filar chromosomes during second division are not found in any Papaver plants except $P$. pinnatifolia thus far studied,

Argemone grandiflora (Fig. 170). This plant, a native of Mexico, has larger PMC. The meiotic chromosomes, 28, are very small in comparison with those of Papaver thus far investigated.

A. mexicana (Fig. 171). This species, however, has 14 meiotic chromosomes, although the chromosome size of this species and the former are almost the same. The basic number in this genus is probably 7, as in Papaver.

Platystemon californicus (Fig. 175). The meiotic number of chromosomes is 6 and they are about two times larger than those of $P$. pavonium and glaucum. At diaphase, the bivalent chromosomes are in the form of 5 rings and a pair of rod. But at metaphase, when they separate to proceed towards both poles, various shapes are observed, though they were rather uniform in shape in the previous stage.

Hunnemannia fumariaefolia (Fig. 174). The PMC are much larger than those of Papaver. The heterotypic chromosomes are small in comparison with the PMC and their shape is rather oblong than spherical. Their number is 28 which is quadruple that of the basic number found in Papaver. The homeotypic chromosomes are extremely small.

Glaucium flavum (Fig. 168). The PMC are larger than those of Papaver. Both heterotypic and homeotypic chromosomes are more oblong than spherical. They are larger than those of Papaver, Hunnemannia and Pteridophyllum.

It is interesting, however, that in the first metaphose the chromosome arrangements of both halves are just the same, while in the second metaphase they are different; one is a circle of 5 with a central one, while the other is a circle of 6 .

G. Serpieri (Fig. 168a). That the present species, being rather larger in external appearances, especially having very much longer capsule than the former species, has only six meiotic chromosomes, was beyond expectation.

Macleya cordata (Fig. 169). The genus Macleya together with Chelidoniums belong to Chelidoniae. The meiotic chromosome number in this species is 10 , while in the latter 6 . 
Pteridophyllum racemosum (Fig. 176). This plant like the previous one, has not been studied karyologically yet. The PMC are rather large in comparison with the size of the flowers. The heterotypic chromosomes are one third or more smaller than those of Papaver investigated. The meiotic number of chromosomes is 9 which has not been found elsewhere in this family yet. Hayata (1930) recently expressed his belief that this plant is quite different from other papaveraceous plants in its floral and stelar structure and therefore put it in a new family Pteridophyllaceae established by him. The validity of this classification is now confirmed in part cytologically by the present writer, for the present meiotic chromosome number 9 is isolated from various numbers of other genera in this family.

Sometimes polyspory is observable. Formerly polyspory was said to be found only in cultivated hybrid plants, but it is also found even in nature. Similar phenomena are also found in Polygonum Thunbergii and P. nipponica.

\section{Lauraceae}

So far as hitherto published results show, the only karyological material was on Cinnamomum Sieboldii by Täckholm and Söderberg (1917). They found the meiotic chromosome number in C. Sieboldii to be 12 .

We studied 2 genera and 4 species whose somatic numbers of chromosomes were 24 .

Cinnamomum Camphora (Fig. 177). 2n $=24$. According to Schürhoff (1926) the cell wall formation in the PMC is carried out by succession, but whether it is done by furrowing or by cell-plate is not certain at present.

\section{Calycanthaceae}

As to the number of chromosomes several records have already been published :

But the genera so far studied were limited to the genus Calycanthus; we now record the chromosome number of the remaining genus, Meratia.

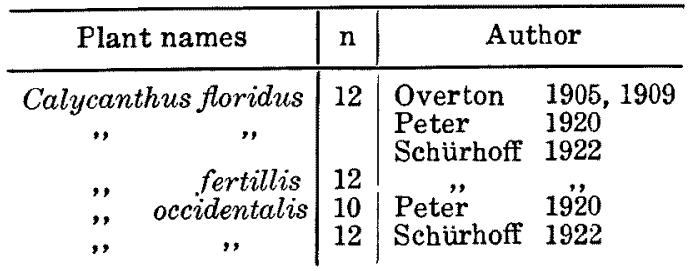

Meratia praecox (Fig. 181). Only somatic chromosomes were studied the number of which is 22 . It is interesting to note that in this family, which has only 2 genera, Calycanthus and Meratia, the different numbers of meiotic chromosomes are found, i.e. 12 (10) in Calycanthus and 11 in Meratia. 


\section{Magnoliaceae}

Considering the chromosome numbers in this family, there are no multiple relations among them even in a genus; for instance in Magnolia the meiotic numbers are 19 , ca.40, ca.45, ca.48, 50, 57(?). Thus a closer study of the chromosome numbers in this family is needed.

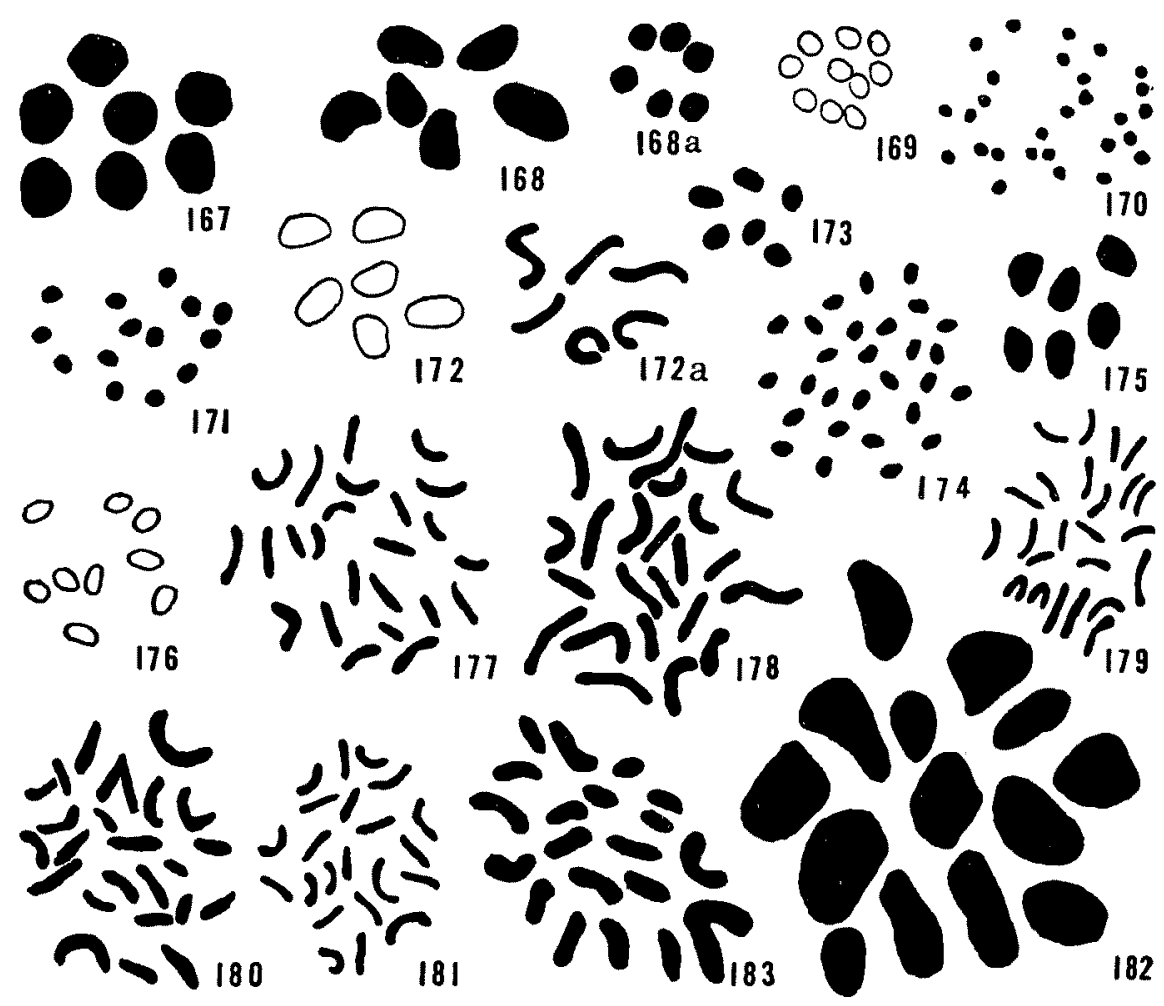

Figs. 167-183. 167. Papaver umbrosum. IM. 168. Glaucium flavum. IM. 168a. G. Serpieri. IIM. 169. Macleya cordata. IA. 170. Argemone grandiflora. IM. 171. A. mexicana. IM. 172. Chelidonium majus. IA. 172 a. ditto. IIM. 173. C. tranchelianum. IM. 174. Hunnemannia fumariaefolia. IM. 175. Platystemon californicus. IM. 176. Pteridophyllum racemosum. IM. 177. Cinnamonum Camphora. Somatic chromosomes. 178. C. japonicum. The same. 179. C. Loureirii. The same. 180. Lindera glauca. The same. 181. Meratia praecox. The same. 182. Michelia compressa. IM. 183. Nandia domestica. Somatic chromosomes.

Michelia compressa (Fig. 182). The meiotic chromosomes, 14, are large and heteromorphic, some of which are 3 times or more larger than the small ones. The homeotype chromosomes are thick and filar (stretched rods) instead of the usual round form as found in other plants. (Cf. Jaretzky in Rumex hispanicus and Polygonum bistorta; Chattway 1926 in Hypericum; Schadowsky 1927 and Nawaschin 1911 in Tradescantia ; Sorokin 1927 in Ranunculus.) 


\section{Berberidaceae}

There were few reports prior to 1928 on this family, but in the same year Tischler, Langlet and others simultaneously published the numbers of chromosomes in Berberis, Mahonia, Podophyllum, Epimedium, Nandia, etc. finding the basic numbers as follows: Podophyllum 6, Diphylleia 6, Epimedium 6, Ranzania 7, Caulophyllum 8, Jefersonia 6, Nandia 10, Berberis 14, Mahonia 14.

Nandia domestica (Fig. 183). 20 somatic chromosomes are counted. They are short thick rods, some of which are bent or V-shaped. The pairing of chromosomes is observed. (Langlet 1928, Morinaga et alii 1929 and Miyaji 1930, $\mathrm{n}=10$ ).

\section{Ranunculaceae}

Although various chromosome counts had been made by several investigators, much work remained to be done in this family. In 1927, Langlet published chromosome counts covering 18 genera, since that time this family has become karyological objects.

Adonis vernalis, var. amurensis (Fig. 184). The meiotic chromosomes are large and oblong rather than spherical, at first metaphase. Their meiotic number is 20 . The behavior of meiotic chromosomes is normal. At the end of interphase they split ready for the next division. In the old tapetum cell "Golgi apparatus" is seen, while in Sinningia younger tapetum cells have this apparatus.

As the numbers of meiotic chromosomes in Adonis are $12(\mathrm{~A}$. dahurica, Takamine, Ishikawa, 1916; Langlet, 1927), 8 (A. apennina, $A$. pyrenaica, $A$. vernalis, Langlet, 1927 a), 16 (A. aestivalis, $A$. autumnalis, $A$. flammea, Langlet 1927 a) and 20 ( $A$, vernalis var. amurensis, 1931 Sugiura), the basic number in this genus is probably 4.

Anemone Hepatica, var. acuta (Fig. 185). There seems to be different numbers of chromosomes in this species and its different varieties. (cf. Langlet 1927, $2 n=14$ in A. Hepatica and 28 in $A$. Hepatica var. multiloba; Moffett 1932, $2 \mathrm{n}=14$ in A. Hepatica and $A$. vernalis). On the other hand the somatic number of chromosomes in our present material is 16 .

\section{Caryophyllaceae}

This family was recently investigated by Rocen (1926), Heitz (1926), Blackburn (1928), Rohweder (1929-34), Ishii (1930) and Sibukawa (1930). Blackburn (1928) studied a large number of meiotic chromosomes covering a number of genera such as Agrostemma, Viscaria, Silene, Endianthe, Lychnis, Petrocoptis, Heliosperma, Melandrium, Cucubalus, Saponaria, Vaccaria, Dianthus, Gypsophila. Thus about 15 genera have been studied now.

Dianthus barbatus (Fig. 187). Blackburn and Rohweder investigated meiotic chromosomes only. Ishii and the present writer independently determined the somatic chromosome number to be 30 . The size of the chromosomes varies; Ishii's figure is about two times longer 
than mine. Perhaps it is due to the difference of varieties of the same species.

D. japonicus (Fig. 188). The meiotic chromosome number is 15 . (Ishii 1930, 2n = 30.)

Silene Keisukei f. minor (Fig. 189). The nucleolus is rather small at diaphase and is very small in early tetrads. The meiotic number of chromosomes is 12. First metaphase chromosomes are spindle-shaped and there is no abnormal behavior during the meiotic division. The first and second meiotic chromosomes are not so different in size. (Cf. Blackburn 1928-'30, $\mathrm{n}=12$ is most numerous in Silene.)

\section{Basellaceae}

Rocén (1927) has investigated Boussigaultia beselloides karyologically and counted the meiotic number of chromosomes to be approximately 20. Since then no new records of the chromosome numbers in this family have appeared.

Basella rubra has 22 meiotic chromosomes (Fig. 190).

\section{Portulaceae}

In this family there are no records of chromosome counting except that Tjebbes (1928) found the number of meiotic chromosomes in Portulaca grandiflora to be 9 and Hagerup (1932) found the numbers 9 and 27 in $P$. oleracea and its var. gigas. We offer here 4 species in 3 genera, namely Portulaca oleracea var. sativa, Calandrinia speciosa, C. umbellata and Telinum patens.

Portulaca oleracea var. sativa (Fig. 191). The PMC are much larger than Hagerup's $P$. oleracea var. gigas, although the meiotic chromosomes are almost as numerous as those of other genera in the same family. The results obtained by Tjebbes and Hagerup in this genus suggest that the basic number of chromosomes is $9(\mathrm{n})$. The meiotic number of chromosomes in this species is $26(3 n-1)$.

Calandrinia grandiflora (Fig. 192). Previously the writer has counted the meiotic numbers of chromosomes in C. speciosa and C. umbellata to be 12 and 10 respectively. The meiotic chromosomes in this species are 8 . In addition to above, the meiotic chromosomes during the first anaphase are only $0.4 \mu$ in diameter, being one half or less of the former two species.

\section{Aizoaceae}

This family has been given little karyological attention for a long time. We now introduce here 5 species of Mesembryanthemum, two species of Tetragonia, and one species of Mollugo.

Mesembryanthemum angulatum (Fig. 199), The materials were sent from France. The first meiotic chromosomes, 9, are shperical, while the second cnes are of filar form. The filar chromosomes at second meiotic division are also found in M. crystallinum. 
M. crystallinum (Fig. 200). The first meiotic chromosomes are as numerous as those of the above species. The second meiotic ones are, on the contrary, smaller than those of the above species.

M. violaceum (Fig. 201). $\mathrm{n}=9$.

M. tenuifolium (Fig. 202). The meiotic chromosomes are spherical, of equal size, and 9 in number.

M. tricolor (Fig. 203). Among 9 meiotic chromosomes 3 are small. It is interesting that the homeotype chromosomes have almost the same size as the heterotypic. The chromosomes of archesporial cells are long thick rods, some of which are curved.

We now know that Mesembryanthemum seems to have two classes from the karyological point of view. The first class has filar chromosomes in the second meiotic division and the second spherical ones. To the former belongs $M$. angulatum and $M$. crystallinum; to the latter $M$. violaceum, tenuifolinum and tricolor.

\section{Phytolaccaceae}

This family was formerly studied by Kleinman (1923) in Phytolacca decandra. He counted the meiotic number of chromosomes to be 18 .

Phytolacca acinosa (Fig. 208). The present writer also counted them in $P$. acinosa to be 18. At diaphase the bivalent chromosomes do not take gemini form, but pairs are so united that they seem to be univalental. (Morinaga et alii 1929, $\mathrm{n}=18$.)

\section{Amarantaceae}

This family had long been forgotten by karyological students when recently Morinaga et alii (1929) took up the study of Celosia cristata. We have studied Achyranthes bidentata and counted the somatic number of chromosomes to be 42 as shown in Fig. 210. (Cf. F. Takagi 1933 in Amaranthus).

\section{Polygonaceae}

The writer, 10 years ago, intended to study some species of Polygonum as there were then no karyological descriptions of it, notwithstanding there were several works on Rumex, etc. in Polygonaceae. He was interested however, to find polyploid plants in Polyyonum. As it was, at first he wrote a short karyological description of Polygonum Savatieri in 1925. On the other hand, Jaretzky also investigating this genus karyologically, published some years later his large work in "Jahrbücher $f$. Wissenschaftliche Botanik 1928."

Thus the karyological study of Polygonum has recently assumed considerable rxtent. As to the collection of materials it is rather troublesome, as Jaretzky (1928) wrote in his paper. Generally, as the number of PMC in an anther is very few -3 or 4 only - therefore one must collect as many flower-buds as possible. Moreover in comparison with Pleuropterus and Reynoutria whose flowers are clusterd, Persicaria has so few flowers in an inflorescence that one is compelled to pull out the young mucilaginous green inflorescence from underneath the sheathes of leaves. Generally, 

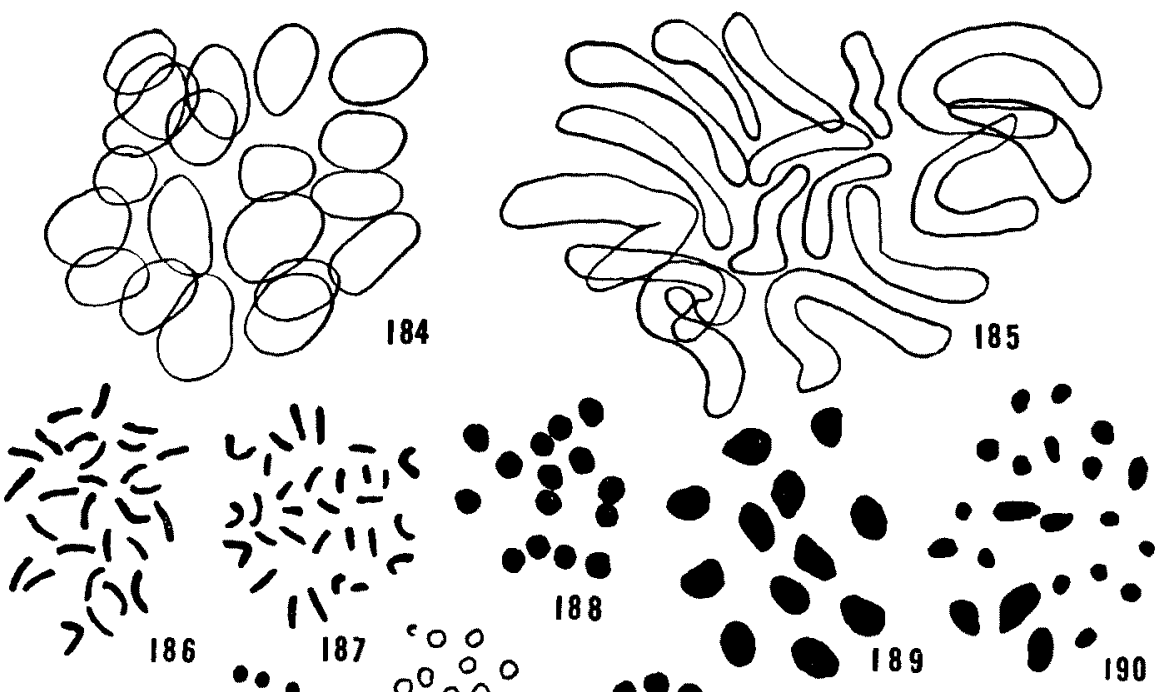

$2,11,1,6$ $30, \frac{110}{20}$

84
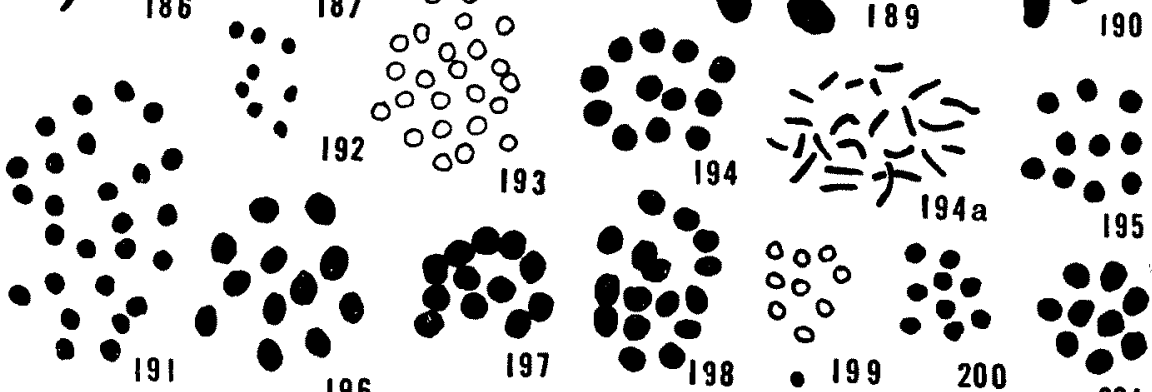

$194 a$

195
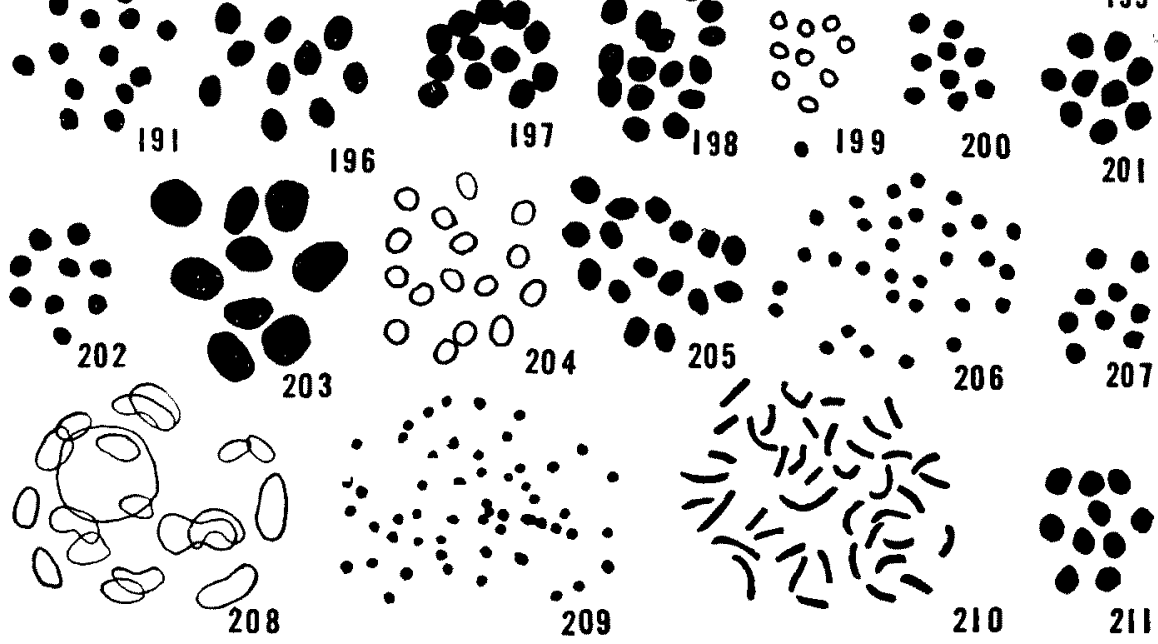

Figs. 184-211. 184. Adonis vernalis var. amurensis. IM. 185. Anemone Hepatica var. acuta. Somatic chromosomes. 186. Euptelaea polyandra. The same. 187. Dianthus barbatus. The same. 188. D. japonicus. IM. 189. Silene Keiskei f. minor. IIM. 190. Basella rubra. IM. 191. Portulaca oleracea var. sativa. IM. 192. Calandrinia grandiflora. IA. 193. C. procumbens. IA. 194. C. speciosa. IA. 194 a. ditto. Somatic chromosomes. 195. C. umbellata. IM. 196. Talinum patens. IM. 197. T. purpureum. IM. 198. Aizoon canariense. IIA. 199. Mesembryanthemum angulatum. IA. 200. M. crystallinum. IM. 201. M. violaceum. IA. 202. M. tenuifolium. IA. 203. $M$. tricolor. IA. 204. Tetragonia echinata. IM. 205. T. expansa. IM. 206. Mollugo verticillata. IM. 207. M. cerviana. IM. 208. Phytolacca acinosa. Diaphase. 209. Rivina humilis. IM. 210. Achyranthea bidentata. Somatic chromosomes. 211. Bilderdykia dumetora. IM. 
floral materials after fixation are so hard especially in Persicaria materials that the blade of microtome-knife is often broken in cutting them. Among various fixing fluids Jaretzky has recommended a fluid composed of 60 parts abs. alcohol, 20 parts chloroform and 20 parts glacial acetic acid as most suitable.

\section{Sex-chromosomes}

Sex-chromosomes in Polygonaceae were first studied by Kibara and Ono (1923) in Rumex Acetosa and afterward by Sinotô (1924) who confirmed their findings. Several other examples were also found by Kihara (1926) and Jaretzky (1927-8). On the other hand, no sex-chromosomes are found in other genera of this family. Formerly Sinotô (1929) has studied Reynoutria sacchalinensis and was unable to find sex chromosomes. We have studied Reynoutria japonica in an attempt to see whether it has sex chromosomes or not. We could find them in XY type which are observed not only in the metaphase side view, but also in the diaphase. Sometimes these proceed ahead of all other autosomes during metaphase progression (Figs. 223, 223 a).

Bilderdykia dumetora (Fig. 211). $\mathrm{n}=10$. (Jaretzky 1928, $\mathrm{n}=10$ ).

Reynoutria (Pleuropterus) japonica (Figs. 223, 223a). $\mathrm{n}=22$.

Our materials were collected in the neighbourhood of Kamikôti-Hot-Spring, Sinano Province and fixed with our Farmer's fluid, in which they were preserved almost a month during a botanical excursion, without any perceptible traces of poor fixation for microseopical examination.

From this material I was able to detect sex chromosomes of the XY type (Fig. 223a) which are connected with each other by a narrow thread in the diakinetic stage. Sometimes these XY allosomes are apt to proceed towards both poles quicker than any other autosomes. Converting the magnification of Sinotô's figure 65a, b (1929) into mine, the size of the chromosomes in $R$. sachalinensis and my $R$. japonica are almost the same. Now it has become evident that the heterochromosomes exist in two genera, Rumex and Reynoutria, of Polygonaceae, though in the latter the heterochromosomes are simple, while in the former there are complex tripatrite chromosomes.

Pleuropterus multiflorus (Fig. 222) having a large tuberous root, is polygamous and used for medical purposes. The flower has a small number of PMC in an anther chamber as in other cases of Polygonum, so it is very difficult to find suitable divison figures. At diaphase there are found 5 ring- and 6 more or less dumb-bell-shaped chromosomes. In the heterotypic anaphase 11 chromosomes are clearly seen neatly arranged at each pole.

Tovara filiformis (Fig. 224). The somatic number of chromosomes was 44 but no different chromosome numbers such as Jaretzky described were found. (Jaretzky 1928, $\mathrm{n}=42-46$.)

\section{Persicaria}

Jaretzky (1928) has already investigated 9 species in this genus. We now enumerate the following 10 species that have been studied karyologically. Choromosome numbers of the last 3 species were reported in my previous paper (1928). 
Persicaria bioritsuensis, P. flaccida, P. hastato-auriculata, $P$. japonica, P. Maackiana, P. Nipponica, $P$. senticosa, $P$. Sieboldii, $P$. tinctoria, $P$. Thunbergii, $P$. perfoliata, $P$. glandulosa.

To collect floral materials for karyological purposes is a difficut task in this genus. As stated above, karyologically suitable materials are only obtained from the very minute green buds under the leaf-sheath.

Persicaria flaccida (Fig. 212). Root-tip-cells were used for the counting of chromosomes. It has 44 somatic chromosomes of moderate length, as in $P$. glandulosa, in spite of the fact that this plant is tetraploid.

P. senticosa (Fig. 217). Only meiotic chromosomes were investigated. At diaphase 11 gemini are arranged clearly as the numerals indicate. Meiosie figures are all normal. Multinuclei in a tapetum cell caused by mitotic division are observed. Similar phenomena were also observed by Håkansson in Celsia.

P. Sieboldii (Fig. 218). Somatic number of chromosomes is 34 . The results of my investigation on Polygonum to date show that, there are only two species, $P$. Sieboldii and $P$. Thunbergii, whose somatic chromosome number is 34 . These chromosomes are small fine rods.

$P$. Thunbergii. The somatic number of chromosomes was already determined to be 34 and published in 1928. The somatic chromosomes are larger than in both $P$. Sieboldii and T. filiformis. At diaphase there are 17 gemini, whose forms are $0,8, \gamma, \|$ and $\backslash$. PMC are much larger than those hitherto studied except in P. bioritsuensis. There are about 3 forms in $P$. Thunbergii, whose colours of flower are white, pink, and white with pink edge. All of them have heteroshaped pollen grains (polyspory). Some of the heteromorphic pollen grains are of almost 1/4 of the normal size. Similar example was also observed in P. japonica and $P$. conspicua.

P. tinctoria (Fig. 219). The somatic chromosomes, 40, are short and rod-shaped, without any of the significant U-shaped chromosomes which were figured by Jaretzky in 1928.

Rumex papilio (Fig. 227). The seeds of this plant were sent from France. The meiotic chromosomes being rather irregular in shaps, are 9 in number, among which three are joined together by the achromatic threads forming a " tripartite chromosome."

The meiotic chromosome number 9 in Rumex was first determined by Ono in Rumex vesicarius (1928). Since that time the basic numbers of chromosomes in Rumex have been 7 and 8, 9 and 10 .

$R$. conglomeratus (Fig. 226) has 9 meiotic chromosomes like $R$. papilio and $R$. vesicarius, though Jaretzky (1928) counted 10.

$R$. nepalensis (Fig. 225). The meiotic chromosomes are much smaller than those of the former species. The number of meiotic chromosomes 


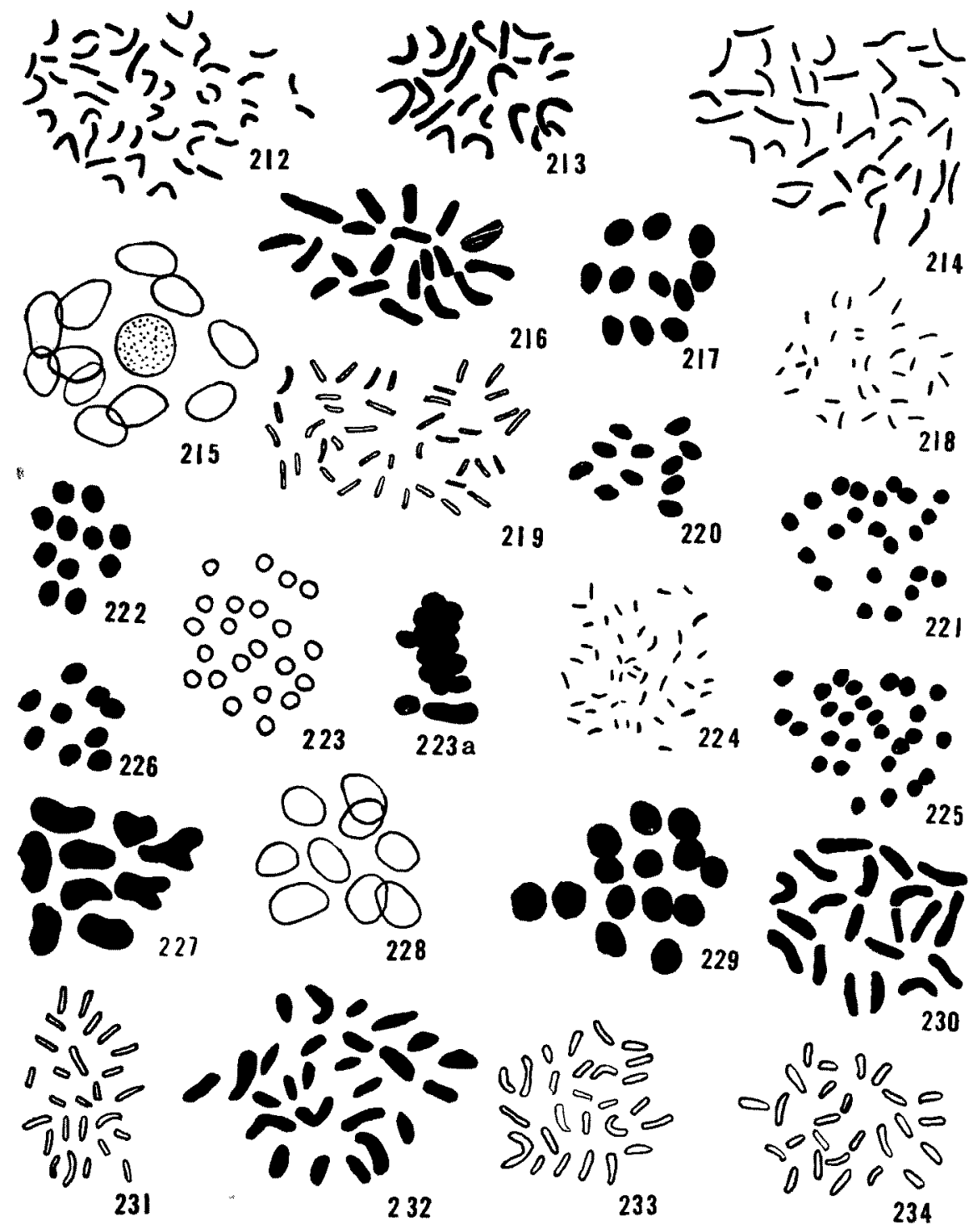

Figs. 212-234, 212. Persicaria flaccida. Somatic chromosomes. 213. P. hastato-auriculata. The same. 214. $P$. japonica. The same. 215. P. Maackiana. Diaphase. 216. $P$. nipponica. Somatic chromosomes. 217. P. senticosa. IM. 218. P. Sieboldii. Somatic chromosomes. 219. P. tinctoria. The same. 220. P. viscosa. IIM. 221. $P$. bioritsuensis. IIM. 222. Pleuropterus multiflorus. IA. 223. Reynoutria japonica. IM. 223 a. ditto. showing sex chromosomes. 224. Tovara filiformis. Somatic chromosomes. 225. Rumex nepalensis. IM. 226. Rumex conglomeratus. IM. 227. $R$. papilio. IM. 228. $R$. vesicarius. IM. 229. Pterostegia drymarioides. IM. 230. Grevillea robusta. Somatic cbromosomes. 231. Ficus Carica. The same. 232. F. elastica. The same. 233. F. lyrata. The same. 234. F. benghalensis. The same. 
is 27. Thus we now know that there is another group whose basic number is 9 or its multiples in addition to the usual one whose basic number is 10 or its multiples.

$R$. vesicarius (Fig. 228). The number of chromosomes in this species was first found by Jaretzky to be 20 in the somatic cells (1928). Several months later Ono found the meiotic number of chromosomes to be 9 in a specimen of the same plant from the Botanical Garden Leyden. The present writer also counted the meiotic number of chromosomes to be 9 in the materials from France, confirming Ono's count, although the sizes of the chromosomes figured by Ono are rather different from his.

Pterostegia drymarioides (Fig. 229). While Polygonoideae has been studied karyologically in recent times, Eriogonoideae has not been studied before. The meiotic chromosome number 14 . This number is rarely found in this family (Koenigia islandica by Hagerup 1926).

\section{Proteaceae}

The present writer studied Grevillea robusta and counted the somatic chromosome number to be 20 (Fig. 230). These are short rods and rather thick. (Ballantine 1909, $\mathrm{n}=12$ in Protea lepidocarpon; Messeri 1928, $\mathrm{n}=8$ in Grevillea macrostachya.)

\section{Moraceae}

This family has received prominent attention because sex chromosomes were found in several species. The genera already studied karyologically at the time I began the present study (1928) were Morus, Humulus and Cannabis. As there were no karyological studies of Ficus, a genus in this family, at that time, we undertook to study several species of this genus. But in the same year Miss Condit also undertook study of plants in the same genus and our results somewhat agee with hers.

Ficus Carica (Fig. 231). Only somatic chromosomes were investigated. As to their number there is no variation ; it is uniformly 26 in spite of Condit's different results. The size and shape of chromosomes in a cell is rather various, some of which are double the size of others.

F. elastica (Fig. 232). The somatic chromosomes are far larger than those in F. Carica. There are various shapes in them; rods, more or less curved, bent, etc. As to the size of chromosomes our findings do not tally with Condit's. (Krause 1930, $2 \mathrm{n}=26$.)

$F$. lyrata ( $F$. pandurata) (Fig. 233). $2 n=26$. (Krause 1930, $2 \mathrm{n}=26$.)

F. benghalensis (Fig. 234). 26 somatic chromosomes which are short, rod-shaped and not so curved as those found in the previous species. (Krause 1930, $2 \mathrm{n}=$ ca. 28).

From the results so far obtaind, the basic number in Fious is 13 . The following table shows the chromosome numbers hitherto determined in the geus Ficus: 


\section{Fagaceae}

This family was recently studied karyologically by Wetzel (1928). According to him the meiotic ehromosome number in Quercus is 11.

Quercus crispula (Fig. 235) has 24 as somatic chromosome number. (Eiler $\mathrm{H} \phi$ eg $1929, \mathrm{n}=12$ in $Q$. robur and Q. sessiliflora.) Jaretzky (1930) pointed out that the numbers of meiotic chromosomes in Quercus, Fagus and Castanea were all 12 and that Wetzel's counts were wrong. Judg-

\begin{tabular}{|c|c|c|}
\hline Pla & e & Author \\
\hline $\begin{array}{l}\text { F. erecta } \\
\text { F. glomerata } \\
\text { F. Carica } \\
\text { F. Carica } \\
\text { F. palmata } \\
\text { F. Panduraefolia } \\
\text { F. Pandurata }\end{array}$ & $\begin{array}{r}13 \\
\text { probably }+14 \\
+13 \\
+13 \\
\\
+13 \\
\text { probably }+12 \\
13 \\
+13 \\
13 \\
+13 \\
\text { probably }+13 \\
+13 \\
+14 \\
\text { probably }+14 \\
+13 \\
\text { probably }+13 \\
\text { probably }+13 \\
\text { probably }+13\end{array}$ & 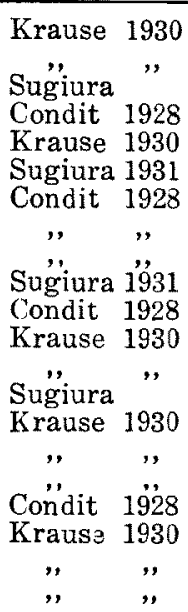 \\
\hline
\end{tabular}
ing from these reports, the correct number of the meiotic chromosomes in Quercus is plobabry 12 and not 11.

\section{Piperaceae}

This family has been comparatively well studied karyologically as shown below :

\begin{tabular}{|c|c|c|c|}
\hline Plant name & $\begin{array}{c}\text { Chromosome } \\
\text { number }\end{array}$ & \multicolumn{2}{|c|}{ Author } \\
\hline $\begin{array}{l}\text { Piper subpeltatum } \\
P . \text { subpeltatum } \\
P . \text { subpeltatum } \\
P . \text { Betle } \\
\text { Peperomia Sintenisii } \\
P . \text { Pellucida } \\
P . \text { resediflora } \\
P . \text { magnoliifolia } \\
P . \text { blanda } \\
P . \text { hispidula } \\
P . \text { verschaffeltii } \\
P . \text { metallica } \\
P . \text { incana }\end{array}$ & $\begin{array}{c}12 \\
\text { ca. } 20 \\
12 \\
16 \\
8 \\
10-12 \\
12 \\
12 \\
\text { ca. } 12 \\
12-14 \\
12 \\
12 \\
11\end{array}$ & $\begin{array}{l}\text { Palm } \\
\text { Haeuser } \\
\text { Johansen } \\
\text { Johnson } \\
\text { Brown } \\
\text { ", } \\
\text { Haeuser } \\
\quad, \\
\text { Johnson } \\
\text { Abel } \\
\quad, \text { aft }\end{array}$ & $\begin{array}{l}1915 \\
1916 \\
1931 \\
1910 \\
1908 \\
1908 \\
1916 \\
\text { "' } \\
1914 \\
1923 \\
\text { "' }\end{array}$ \\
\hline
\end{tabular}

Considering these numbers, they are chiefly multiples of 4 (cf. the table).

Peperomia Sandersii var. argyreia (Fig. 236). Materials used were grown in the green house. The PMC of Peperomia seem to be much larger than those of Piper accord-

ing to Johansen's figures of Piper (1931). The gemini at diaphase are relatively large in comparison with the size of metaphase chromosomes. The meiotic chromosomes in this plant are 12 in number.

\section{Casuarinaceae}

The number of meiotic chromosomes in this family was first counted by Juel $(1902,1903)$ in Casuarina stricta.

Casuarina stricta (Fig. 257). The somatic number is 18. (Juel, $\mathrm{n}=8-12$, Wetzel $1929, \mathrm{n}=$ ca.12 in C. montana, C. equisetifolia and C. stricta.) 


\section{Zingiberaceae}

There was no karyological record until the somatic number of chromosomes was found to be 22 in Zingiber officinale by the present writer (1928). A year later Morinaga et alii counted the somatic number of chromosomes of $Z$. Mioga to be 55(?). According to the verbal information of Takenaka (1932), Z. Mioga studied by him had also the same number of chromosomes.

Curcuma longa (Fig. 238). Materials were collected from the Luchuan Islands where the present plant was cultivated. It was kindly given me by Mr. S. Sonohara to whom I wish to express my cordial thanks. The somatic chromosomes are all short and rodshaped, instead of long as seen in Zingiber.

\section{Iridaceae}

This family had been neglected by karyological students for a long time since Strasburger (1900) and Miyake (1905) studied some Iris plants, until when it was studied again by Heitz (1926). Since that time Kazao (1925, '29), Delaunay (1928), Simonet $(1928,30)$, and Longley (1928) have determined the numbers of chromosomes among various species. Thus at present more than 80 species of Iris have been studied and their chromosome numbers counted; ,most of the numbers are for somatic chromosomes, however. Besides, the number of chromosomes in Crocus, Freesia, Sisyrinchium, Hermodactylus, and Gladiolus has also been counted by several investigators during the past few years.

Crocus sativus (Fig. 240). $2 \mathrm{n}=24$. (Himmelbaur 1926, $2 \mathrm{n}=24$; Morinaga et alii $1931,2 \mathrm{n}=24$ ).

Gladiolus gandavensis (Fig. 241). $2 \mathrm{n}=64$. (de Vilmorin et Simonet $1927, \mathrm{n}=30$ in G. primulinus; Hosono $1931,2 \mathrm{n}=60$ in 63 garden varieties of $G$. grandavensis).

G. Colvillei (Fig. 242). This plant was raised in 1823 at Colville's Nursery, Chelsea, England, the progeny of G. concolor $\times$ G. cardinalis. The somatic chromosomes (32) in root tip-cells are much smaller than the former.

\section{Amaryllidaceae}

Karyological studies in this family are very numerous recently. As the plants have bulbs or rhizomes from which roots come out easily, the greater part of the numbers of chromosomes hitherto determined is almost confined to the somatic. Recently triploid plants have be nn found such as Lycoris radiata (Nishiyama 1928, Inariyama 1931), L. squanmigera (Takenaka 1930); they are all sterile plants.

Crinum maritimum (Fig. 244). Seeds were obtained through the courtesy of Mr. Fukuda in 1927 and were sown in sand. Somatic chromosomes are large thick rods of unequal length as shown in the figure. The number was said to be 18 (1931), but after careful counting it has been found that 24 is correct as Stenar (1925) found. According to Prof. Nakai of Tokyo Imperial University, the Crinum latifolium of Thunberg might be this species. 
C. gigas (Fig. 245). This plant, grown in the Bonin Islands, is 6 feet high; the length of leaves is 6 feet long and 1 foot wide. The somatic chromosome number is the same as the former species, that is, 24 .

\section{Liliaceae}

Many genera in this family have been studied karyologically since the begining of 1880 , but there had been no karyological account of Asparagus until Shoji and

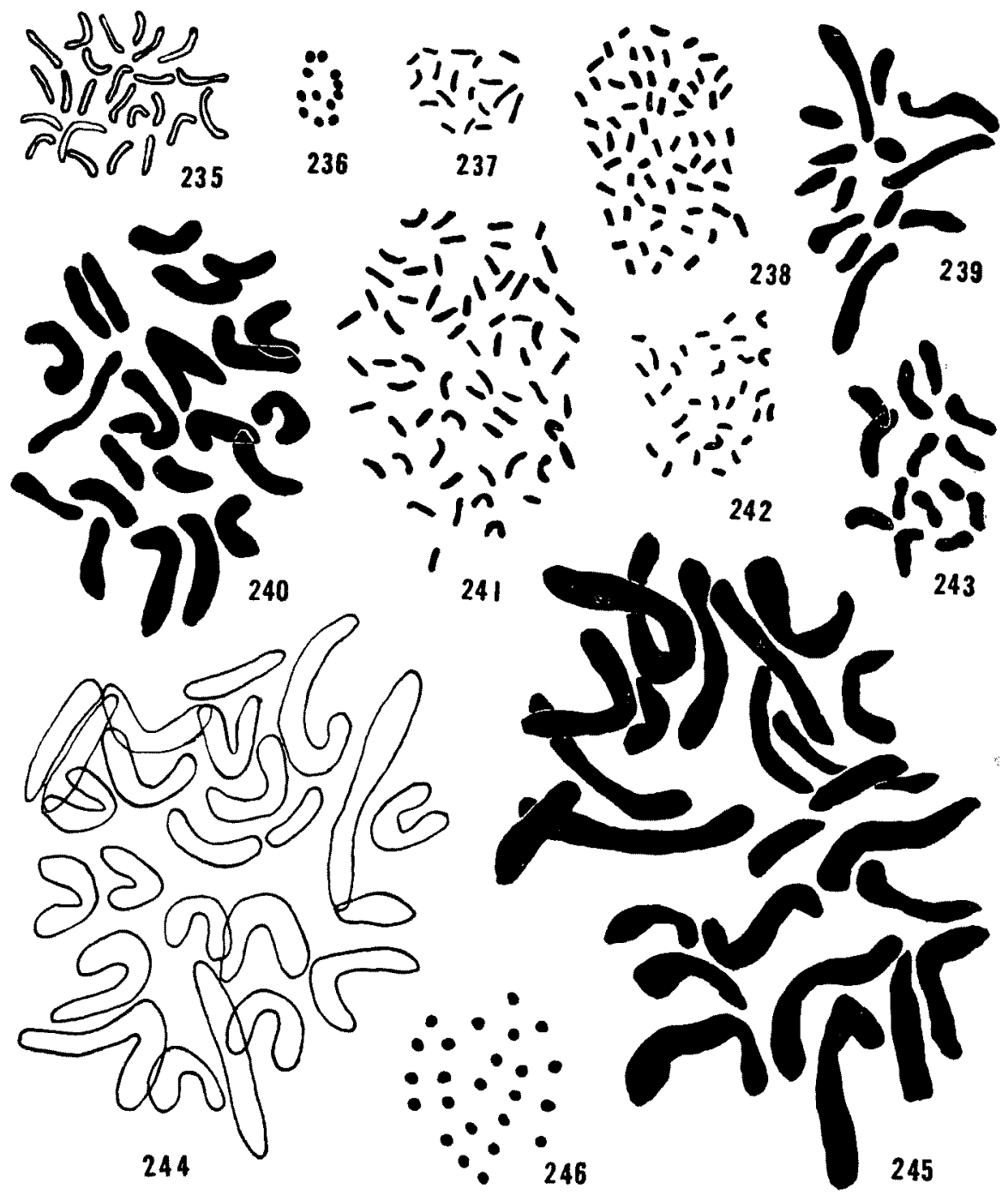

Figs. 235-246. 235. Quercus crispula. Somatic chromosomes. 236. Peperomia Sandersii var. argyreia. II M. 237. Casuarina stricta. Somatic chromosomes. 238. Curcuma longa. The same. 239. Babiana stricta. The same. 240. Crocus sativus. The same. 241. Gladiolus gandavensis. The same. 242. G. Colvillei. The same. 243. Sparaxis tricolor. The same. 244. Crinum maritimum. The same. 245. C. gigas. The same. 246. Asparagus Sprengeri. IM. 
Nakamura (1928) and Kamo (1929) studied A. officinalis. According to Kamo's results, there are 10 meiotic chromosomes, 6 of which are larger than the other; no heterochromosomes were observed.

Asparagus Sprengeri (Fig. 246). Meiotic chromosomes, 24, are all spherical (Kuhn 1930, 2n = 30). From the results, it can be said that there are both tetraploid and pentaploid, supposing 6 as a basic number.

\section{Cleavage Furrow}

The observation of a cleavage furrow in Dicotyledonous plants was first made by Naegeli in Bryonia in 1842, but he believed that the dividing layers were of the nature of cell plates and not an ingrowth of the cell wall: "Auf der innern Oberflaeche der Membran sechs vorspringende Leisten; denn ploetzlich die Bildung von Scheidewaenden, die sich in Centrum beruehren." Since then many investigators have followed ; Wimmel, von Mohl, Hofmeister, Digby, Cannon, Fraser, Shoemaker, and many others, including Tahara, Ishikawa, Yamaha and the present writer.

Since Strasburger's famous paper “Über Zellbildung und Zelltheilung" was published (1875), his tetrads-formation by cell-plates has been generally accepted, although Baranetsky, 1880, showed two figures of Hesperis matronalis with incipient furrows along the equator, saying "Strasburger gibt an daß in allen Faellen der Theilung der secundaeren Kerne die Bildung einer Zellplatte zwischen ihnen vorausgeht. Bei den von mir ueberhaupt beobachteten Dicotylen: Pisum sativum, Lathyrus odoratus, Hesperis matronalis, Ipomaea tricolor, konnte ich diese Angabe nicht bestaetigt finden." Farr (1916) has summarized the former observations of cytokinesis by furrowing and writes: "Strasburger followed the next year with his famous work on the formation of cell-plates in a great many plants, in which he included drawings of what he interpreted as cell-plates in the pollen-formation of Tropaeolum majus. This is the most complete series of stages in division of the pollen mother cells of any dycotyledon that Strasburger has ever published, his other studies presenting merely single drawings. A careful survey of these drawings of Tropaeolum reveals apparently swellings of the spindle fibres at the equator, but the evidence that these form a plate is by no means convincing. When it is remembered that this material was fixed in alcohol, and that Strasburger repeatedly expressed his opinion that the pollen mother cells of dicotyledons were very unfavorable material for study, there arises a grave doubt as to whether we are justified in accepting these drawings as final proof of the existence of true cell plate formation in this species. In his discussion he recognized an "Einschnuerung" of the mother cell, and a thickening of the wall at the equator in the form of a ridge." 
Farr denied the existence of cell plates in meiosis of Tropaeolum after a careful investigation. Our observation in Tropaeolum was just the same as Farr's, that is, no cell plates such as Strasburger observed were found. Recently Yamaha (1926) investigated a lot of plants in an attempt to find furrowing and he described nineteen cases. In the majority of these he saw transitional cell plates even though they soon vanish away and play no part in cytokinesis.

Summarizing the results already obtained, it seems that the furrowing process is only carried out in simultaneous pollen cell formation; on the contrary, cell plate formation occurs in the successive type of formation. Formerly there were no examples in which the process of partition wall formation of pollen mother cells could be converted experimentally in the same plant. Sakamura and Stow (1926), however, succeeded in carrying out this interesting experiment. In spite of the fact that the pollen cells of Gagea lutea are usually formed by the cell plate method, they can be also made by the furrowing process when temperature is raised above $25^{\circ} \mathrm{C}$. Similar phenomena were also observed by them in Hyacinthus, Tulipa, Crocus, and Aconitum. Yasui (1931) and Leffingwall (1932) found both simultaneous and successive divisions in the same anther in Camassia. According to Zaccharias (1888, 1901, 1903), Lundegårdh (1912), and Yamaha, cell plates were not found in living cells. According to Yamaha's opinion (1921-22) they are probably artifact because they were variously fixed by the kinds of fixatives used, while Yasui observed the cell plate formation in living PMC of Allium and Crepis.

According to my investigations and those of Farr, Yamaha, and others the furrowing process in higher plants seems to be widely distributed not only in Sympetalae, as formerly held, but also in the majority of Archichlamydeae (cf. Table 1). When we study further the plants whose partition wall formation was formerly known to be made by cell plates, we often notice starch grains or other granules lying in the same place as cell plates,

\begin{tabular}{|c|c|c|}
\hline Tropaeolum & 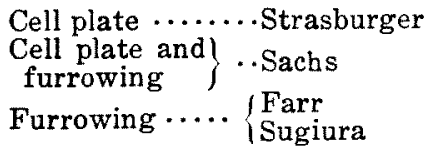 & $\begin{array}{l}1875 \\
1874 \\
1916 \\
1925\end{array}$ \\
\hline Melandryum & $\left.\begin{array}{l}\text { Cell plate } \\
\text { Furrowing }\end{array}\right\} \cdots\left\{\begin{array}{c}\text { Strasburger } \\
,\end{array}\right.$ & $\begin{array}{l}1910 \\
1925\end{array}$ \\
\hline Althaea & $\begin{array}{l}\text { Cell plate } . . . . . \text { Wimmel } \\
\text { Furrowing some- } \\
\text { times accom- } \\
\text { panied by a cell } \\
\text { plate } \\
\text { Furrowing ........ Sugiura }\end{array}$ & $\begin{array}{r}1850 \\
1853 \\
1931\end{array}$ \\
\hline Lavatera & $\begin{array}{l}\text { Cell plate } . . . \cdots \text { Byxbee } \\
\text { Furrowing } . . . \cdots \text { Sugiura }\end{array}$ & $\begin{array}{l}1900 \\
1931\end{array}$ \\
\hline $\begin{array}{l}\text { Chrysan- } \\
\text { themum }\end{array}$ & $\begin{array}{l}\text { Furrowing ........ Tahara } \\
\text { (of the PMC wall) }\end{array}$ & 1915 \\
\hline Crepis & Cell plate ....... Yasui & 1931 \\
\hline
\end{tabular}


but we find no actual cell plates as Strasburger and others figured. Some of the results are tabulated in p. 585 .

The fact mentioned above was also pointed out by Farr (1916).

It seems unquestionable from our investigation and that of Farr, Yamaha, and others, pollen formation by furrowing is widely extended in Dicotyledons. From the fact that the furrowing process is widely found among almost all Dicotyledonous and some Monocotyledonous plants it can now be said at least that the furrowing process is widely extended throughout both plants and animals, though exceptions occur.

At the time Farr's paper was published in 1916 there were only 21 plants in which the furrowing process was investigated, but now it is known in more than 260 plants, covering the majority of families, including both Archichlamydeae and Sympetalae as well as some Monocotyledons, although already the furrowing process had been previously observed in the majority of Sympetalae and few of Archichlamydeae.

Formerly in cytokinesis a Monocotyledon type (bipartition type, "Sukzedaner Teilungstypus", "Zweimaliger Zweiteilungstypus”) and a Dicotyledon type (Quadripartition type, "Simultaner Teilungstypus") were distinguished by Strasburger and he showed in the former type the spindle axes of the second division perpendicular to each other, while those of the latter type appear in his figures parallel to each other. But this distinction disappeared after the works on Papaver (Yasui 1921), Cannabis (McPhee 1924), Tropaeolum (Sugiura 1925), Polygonum (Sugiura 1925), etc. were published, for they pointed out that the spindle axes were not always parallel to each other in Dicotyledons but sometimes perpendicular and at other times placed at various angles to each other. As to which is more advanved, the successive pollen mother cell division or the simultaneous, there were hitherto two theories. One was held by Schürhoff (1926), Ziegenspeck (1927), Schnarf (1927), etc. that the simultaneous pollen mother cell division to be more advanced than the other, while Süssenguth (1920), Tischler (1921/22), Goebel (1923), and others held that the simultaneous pollen mother cell division was more primitive. Tischler (1929) also said that "Ich glaube, der Streit ist ziemlich fruchtlos, vielleicht fahren wir am besten, wenn wir mit Engler (1926) dem Merkmal überhaupt keinen hohen systematischen Wert zusprechen, dagegen für die Gruppierung innerhalb gewisser Familien den Modus der P.M. Zellteilung als unterscheidungsmerkmal zulassen." We believe that in another sence, these differences of opinion are quite irrelevant, for as stated above these two modes of pollen mother cell division cannot be differentiated strictly, one from the other. Our own investigation shows that the so-called simultaneous division does not occur precisely as the term implies, but that occasionally the first furrow appears at the end of the first meiotic division. 
Table 1

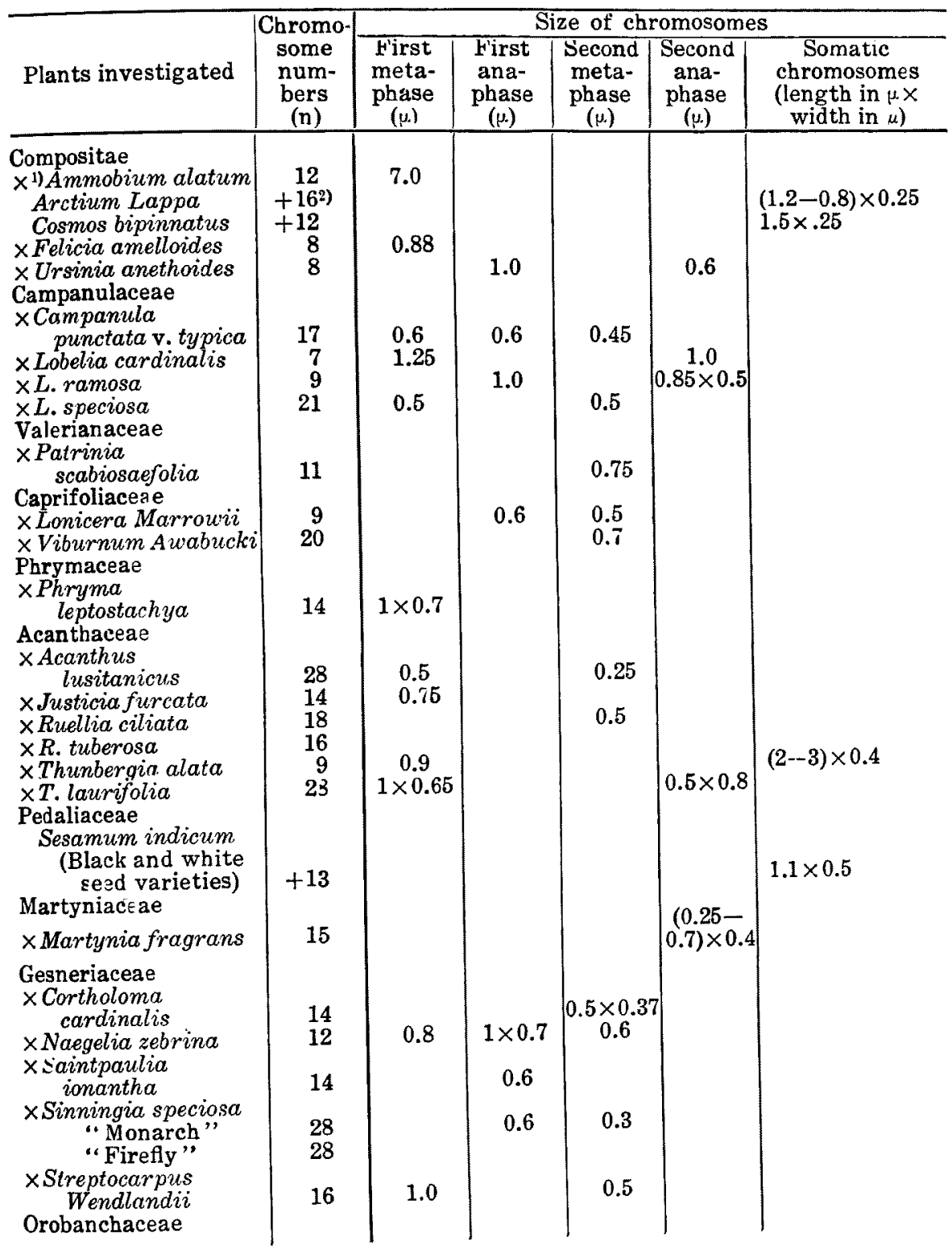

1) $\times$ denotes that in these plants the cy tokinesis takes place by furrowing method. About other examples refer to Schnarf's Embryologie d. Angiospermen (1927). In addition to the plants in this table we found the following exacentra spectabilis, umbellata, Chloranthus serratus, C. glaber, C. inconspicuus, Dicentra macrophylla, Heliophyla, Begonia sempelflorens, Mammillaria Iloch, Valeriana officinalis, Plantavar. trilobata, Trigonotis peduncularis, Pals, Crepis rubra, C. foetida, C. alpina. go major var. asiatica, Valeriana offeinalis, Crepis from the diploid number of chromo$2)+$ indicates that this number is presumed from the somes counted. 
Table 1 (Continued)

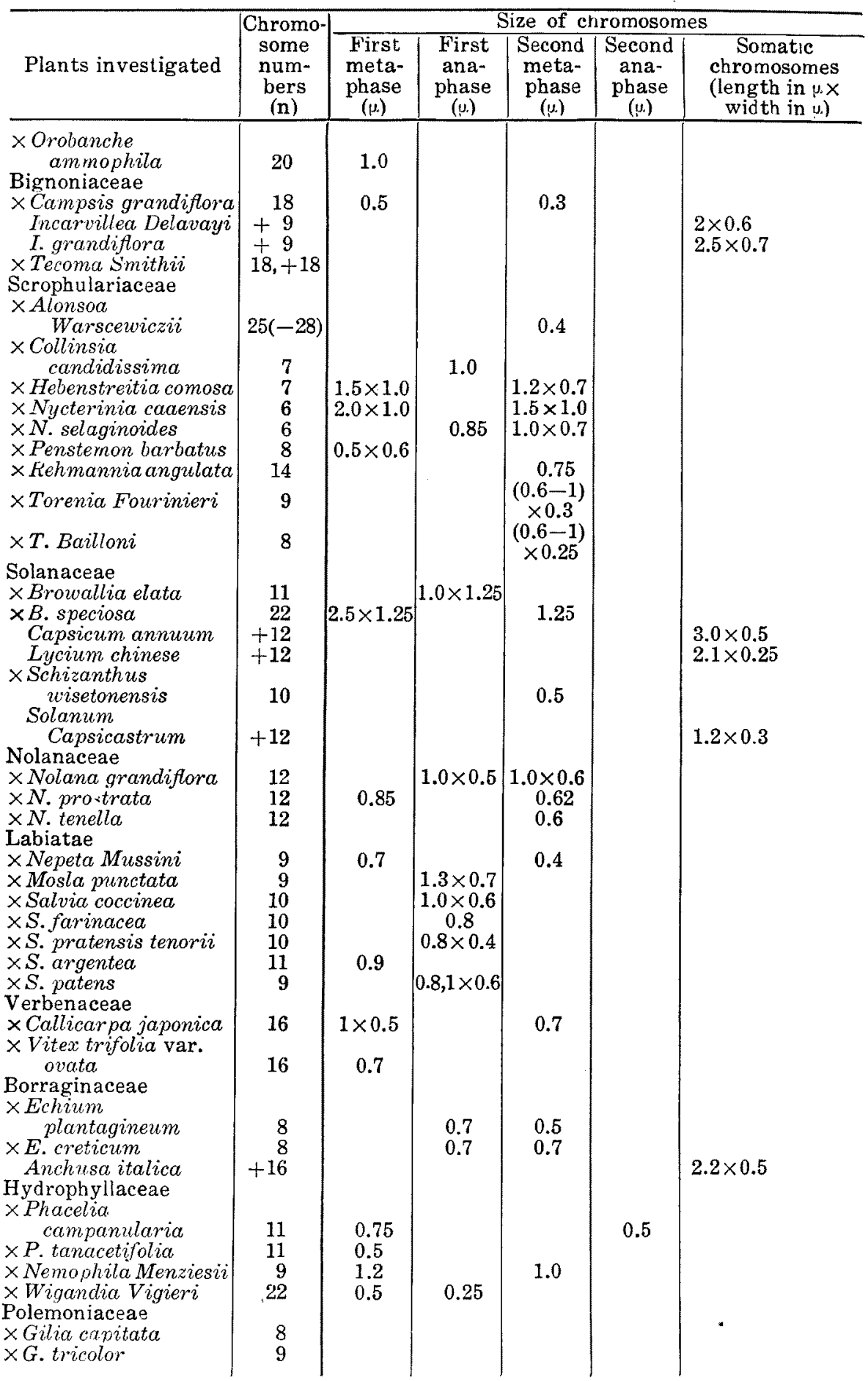


Table 1 (Continued)

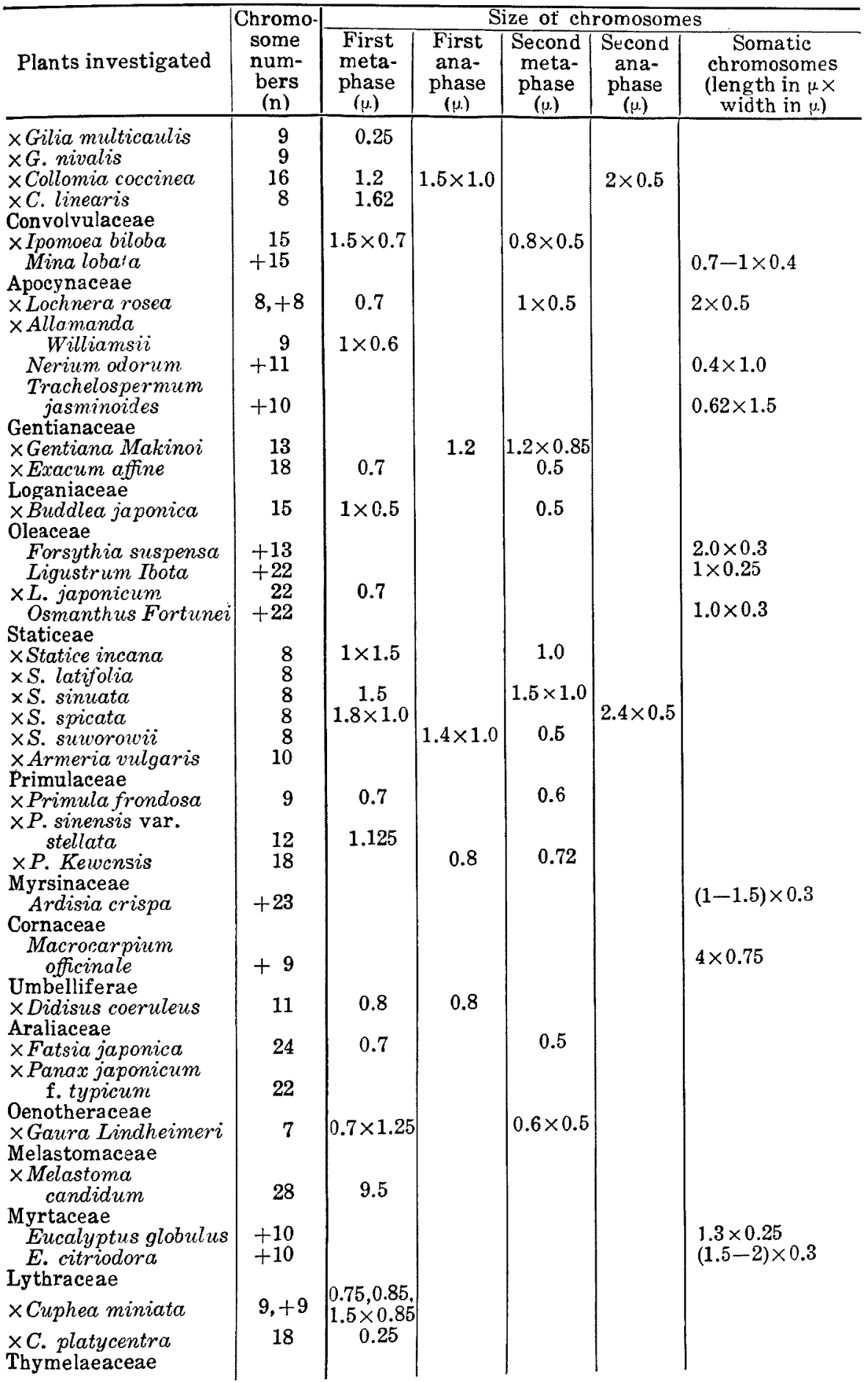


Table 1 (Continued)

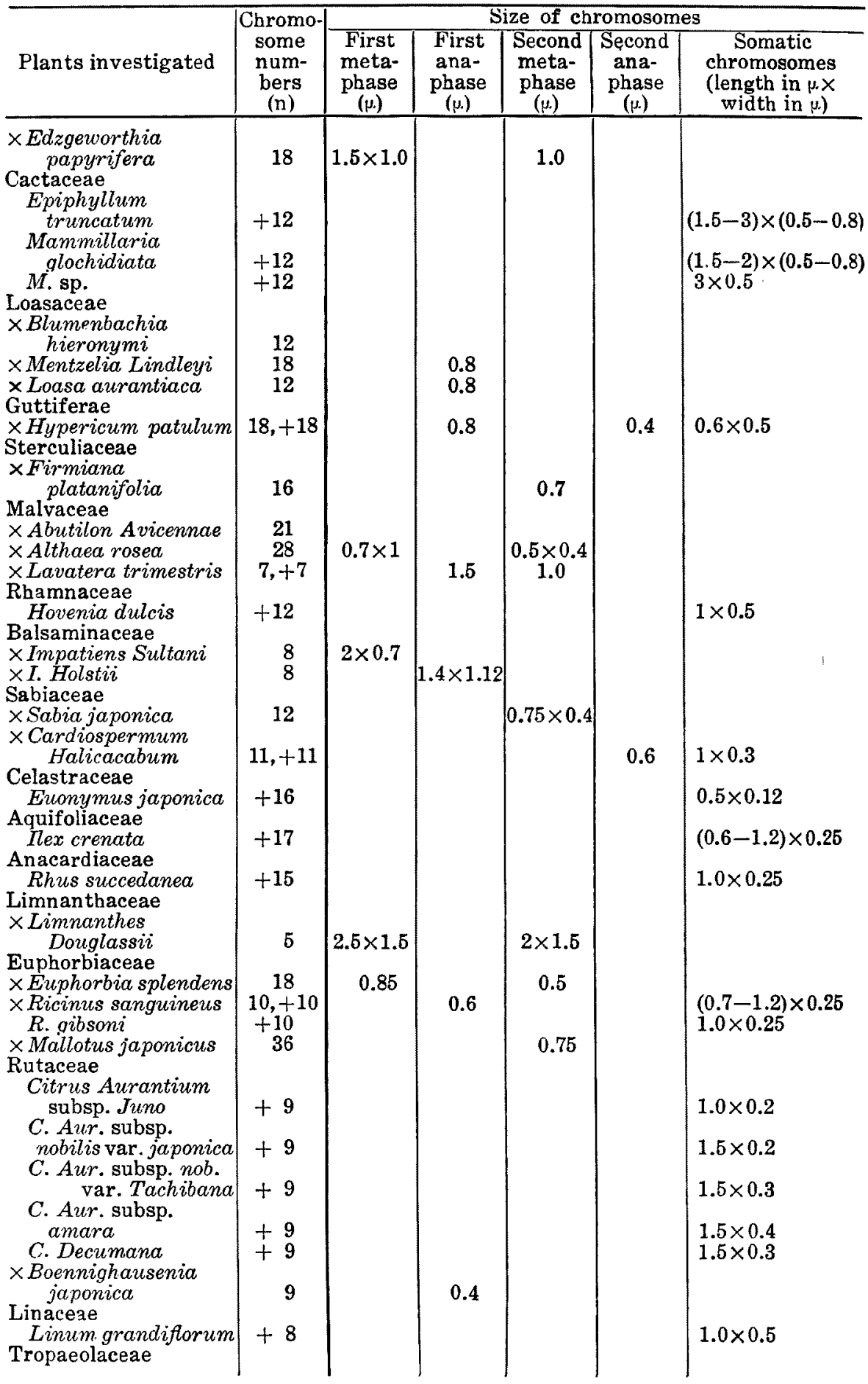


Table 1 (Continued)

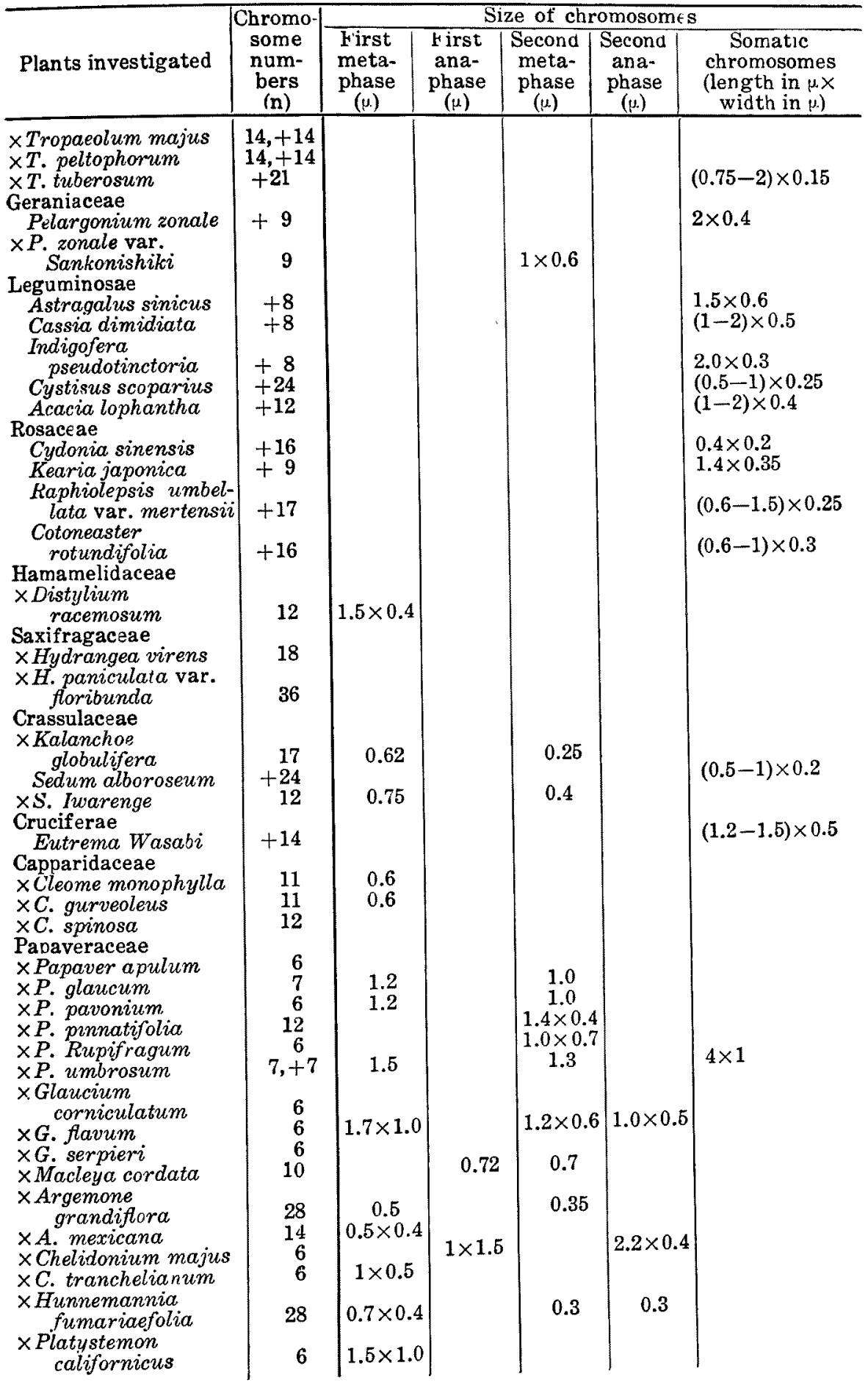


Table 1 (Continued)

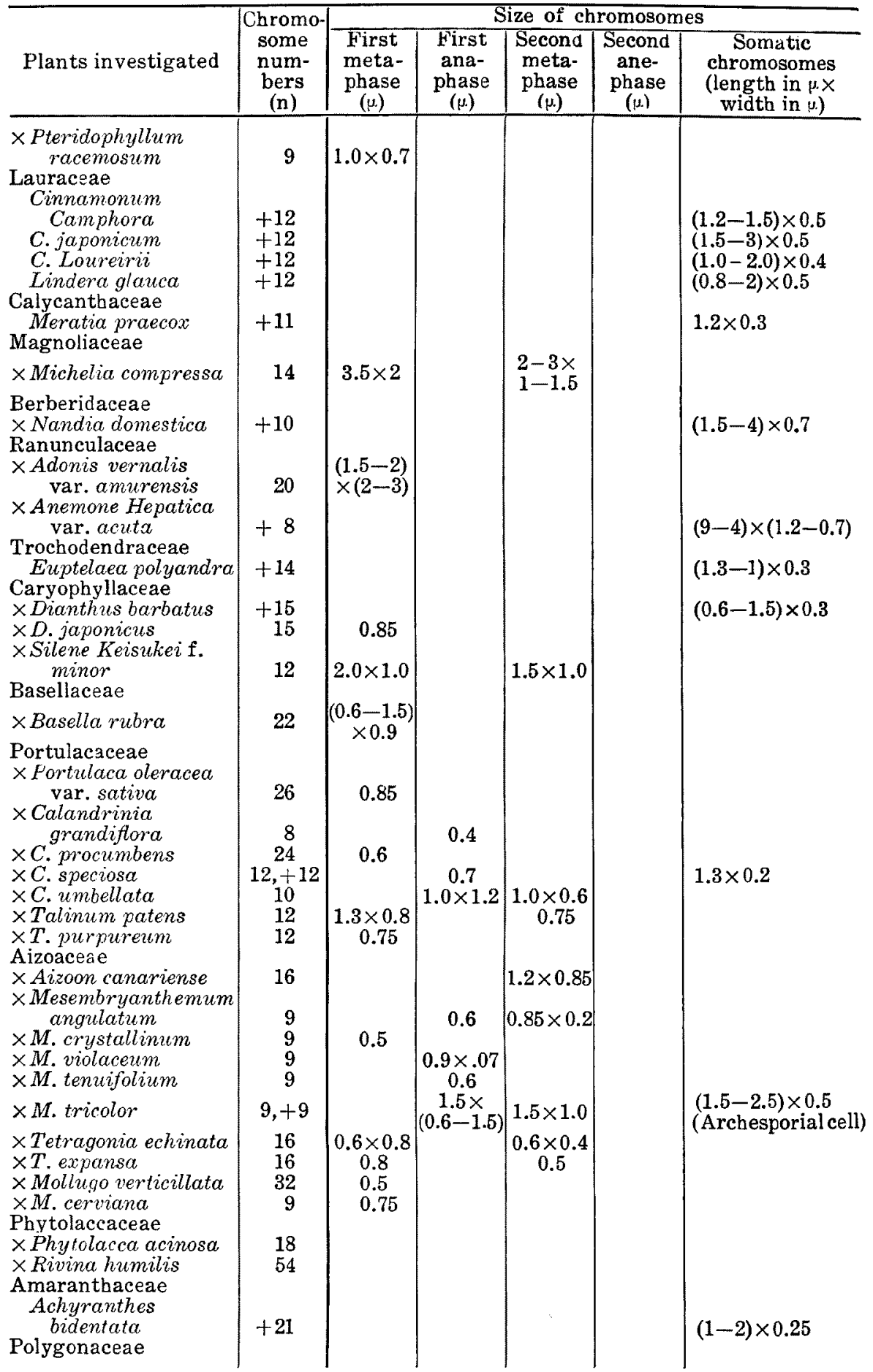


Table 1 (Continued)

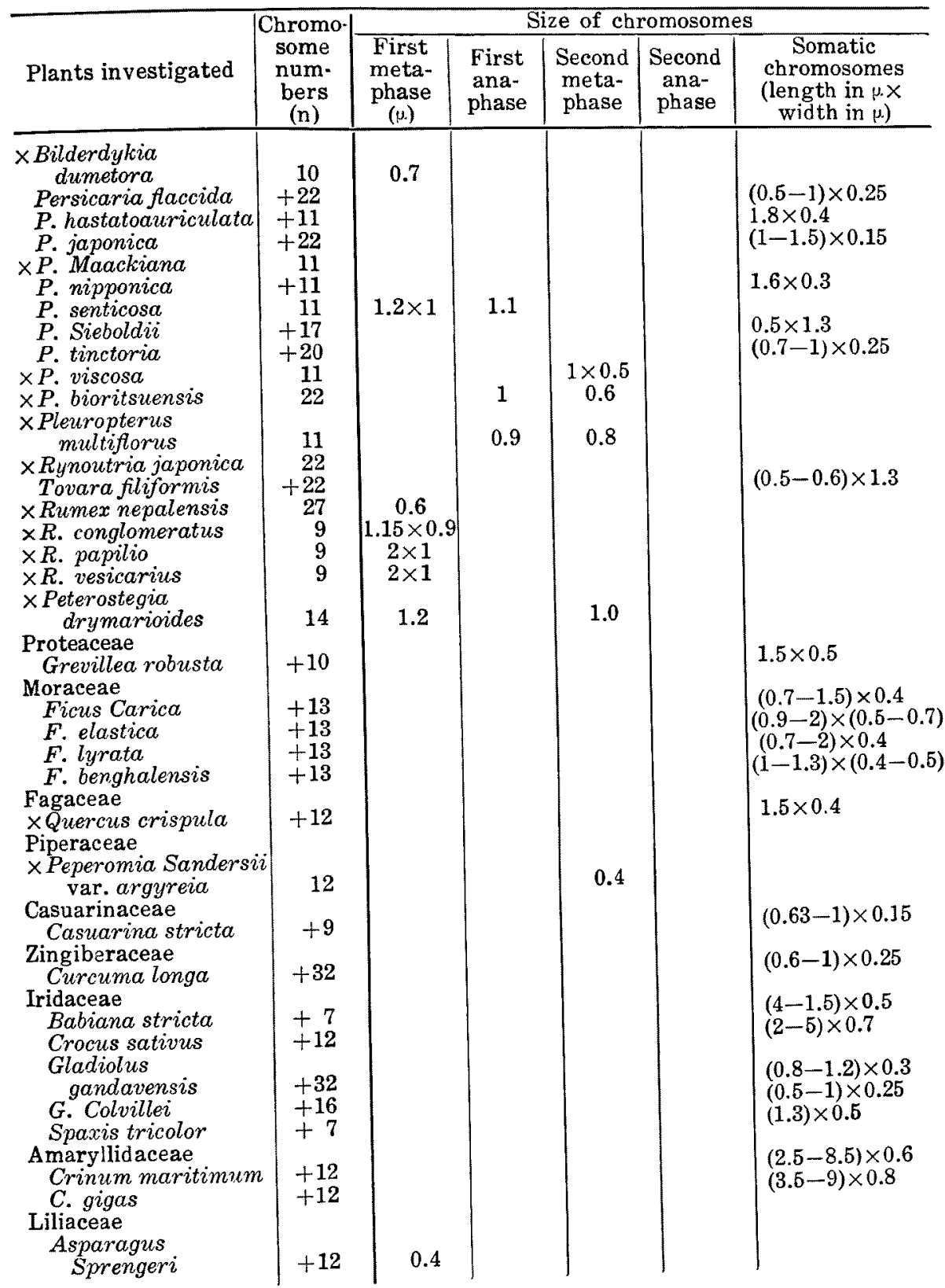

\section{Summary}

Since I published "Cytological Studies on Tropaeolum majus" in 1925, I have been continually engaged in the karyological investigation of more than 260 species, covering 82 families, including both Mono- 
cotyledons and Dicotyledons (cf. Table 1 in which 81 families, 250 forms including 233 species are listed).

1) Throughout the present study I have used modified Farmer's fixative exclusively for the fixation of materials of both flower buds and root-tips, and have had favourable results.

2) I usually found one more or one less chromosome in related plants instead of a polyploidal relation. In some cases the cause of this seemed to be explained by chromosome fusion during diaphase.

3) In the plant groups investigated in the present work polyploidy and aploidy are both found. Discussion on these phenomena among others is left until further study on chromosome numbers in many more plants or plant groups has been made.

4) The chromosome sizes during meiotic and somatic nuclear divisions were measured (cf. Table 1).

5) True cell plate formation was not observed in the plants used in the present work.

6) Considering the works of previous authors together with the present case it may be concluded that the furrowing process during the formation of partition wall of pollen mother cells prevails in the Dicotyledonous plants and is found also in some Monocotyledons.

The expense of carrying out the present study was partly defrayed out of a grant from the Educational Department, and from the Foundation for the Promotion of Industrial and Scientific Research of Japan, to the authorities of which the writer wishes to express his best thanks.

\section{References}

Farr, C. H. 1916. Cytokinesis of the pollen mother cells of certain Dicotyledons. Mem. N. Y. Bot. Gard. 6.

Gaiser, L. O. 1926. A list of cbromosome numbers in Angiosperms. Genetica 8.

- 1930. Chromosome numbers in Angiosperms. II. Bibliog. Genet. 6.

- 1931. Do. III. Genetica 12.

- 1934. Do. IV. Bibliog. Genet. 10.

Kihara, H., Yamamoto, Y. and Hosono, S. 1931. A list of chromosome-numbers of plants cultivated in Japan (Reprinted from "Studies on chromosomenumbers of plants "). Tokyo.

Schürhoff, P. N. 1926. Die Zytologie der Blïtenpflanzen. Stuttgart.

Sakamura, T. and Stow, I. 1926. Über die experimentell veranlasste Entestehung von keimfähigen Pollenkörnern mit abweichenden Chromosomenzahlen. Jap. Jour. Bot. 3.

Sinotô, Y. 1929. Chromosome studies in some dioecious plants, with special reference to the allosomes. Cytologia 1.

Sugiura, T. 1928. Chromosome numbers in some higher plant I. Bot. Mag. (Tokyo) 42.

- 1931. A list of chromosome numbers in angiospermous plants. Bot. Mag. (Tokyo) 45.

— 1936. Do. II. Proc. Imp. Acad. (Tokyo) 12. 
Tahara, M. 1915. Cytological studies on Chrysanthemum (Japanese). Bot. Mag. (Tokyo) 29.

Tischler, G. 1921-2. Allgemeine Pflanzenkaryologie. Berlin.

- 1927. Pflanzliche Chromosomen-Zahlen. Tab. Biol. 4.

— 1929. Verknüpfungsversuche von Zytologie und Systematik bei den Blütenpflanzen. Ber. Deut. Bot. Ges. 47.

- 1931. Pflanzliche Chromosomen-Zahlen (Nachtrag Nr. 1). Tab. Biol. Period. 1, (Tab. Biol. 7).

1934. Allgemeine Pflanzenkaryologie. (Der Ruhekern). Berlin.

Yamaha, G. 1926. Über die Zytokenese bei der Pollentetradenbildung, zugleich weitere Beitrăge zur Kenntnis uiber die Zytokinese in Pflanzenreich. Jap. Jour. Bot. 3.

Yasui, K. 1931. Cytological studies in artificially raised interspecific hybrids of Papaver. III. Unusual cases of cytokinesis in pollen mother-cells in an $\mathrm{F}_{1}$ plant. Cytologia 2. 